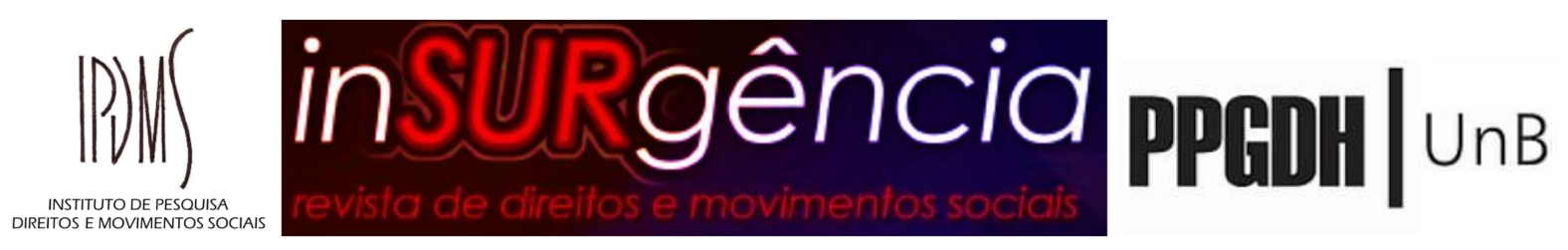

\title{
“Ô MEU SENHOR, É UMA ORDEM SUPERIOR!"’: análise da execução de ordens de despejo em conflitos fundiários urbanos em Fortaleza-CE.
}

“OH MY LORD, THIS IS AN ORDER FROM UP THERE!': an analysis of eviction orders in urban land conflicts in Fortaleza-CE.

Patrícia Oliveira Gomes ${ }^{2}$

Resumo: $\mathrm{O}$ artigo tem por objetivo problematizar a prática do despejo forçado em conflitos fundiários urbanos como uma medida normal a ser tomada no início do processo. Para tanto, a partir de uma pesquisa qualitativa, foram analisadas decisões judiciais de primeira instância em ações possessórias coletivas ajuizadas em varas cíveis em Fortaleza-CE, no período de 2010 a 2014, que reivindicavam a posse de imóveis privados. Discuto a contradição entre a naturalização do despejo forçado em conflitos fundiários e a sistemática de regras e princípios do processo civil constitucionalizado e das normas internacionais a respeito.

Palavras-chave: despejo forçado, conflito fundiário urbano, garantias processuais

Abstract: The article aims to problematize the practice of forced eviction in urban land conflicts as a normal measure to be taken at the beginning of the judicial process. To this end, in a qualitative research, first instance court decisions were analyzed in collective possession lawsuits filed in civil courts in Fortaleza-CE, from 2010 to 2014, which discussed the possession of private property. I discuss the contradiction between the naturalization of forced eviction in land conflicts and the rules and principles of constitutionalized civil proceedings and international norms in this regard.

Keywords: forced eviction, urban land conflict, procedural guarantees

\footnotetext{
${ }^{1}$ Trecho da música "Despejo na favela" de Adoniran Barbosa.

${ }^{2}$ Mestre em Direito Constitucional pela Faculdade de Direito da Universidade Federal do Ceará. Advogada com atuação em Direitos Humanos e Assessoria Jurídica Popular.
} 


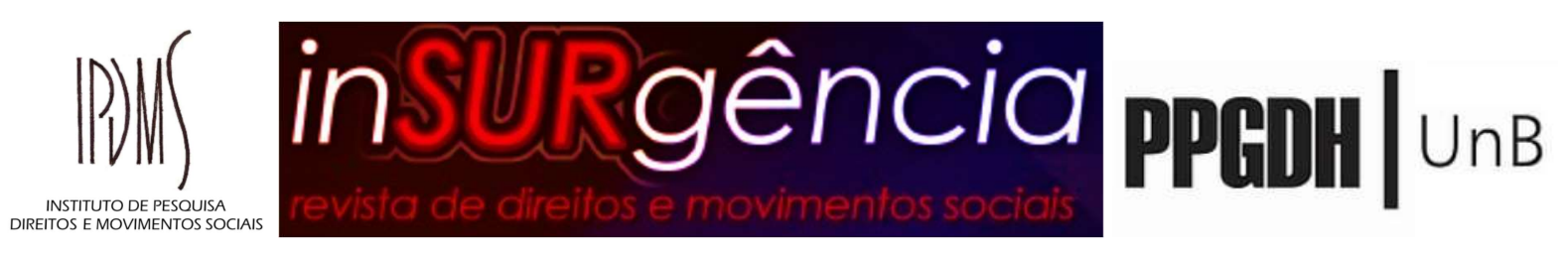

\section{Introdução}

Este artigo tem por objetivo abordar a prática do despejo forçado em conflitos fundiários urbanos como uma medida normal a ser tomada no início do processo. Discuto a contradição entre a naturalização do despejo forçado em conflitos possessórios e o conjunto de regras e princípios do processo civil constitucionalizado e das normas internacionais a respeito.

A execução das decisões judiciais torna-se o momento ápice da violação de direitos fundamentais materiais e processuais, legitimadas em ritos e construções interpretativas que soam antiquadas diante da transformação do direito civil e processual civil.

A celeridade marcante do rito especial possessório fundamenta-se na necessidade de proteção à posse enquanto externalização, aparência de propriedade, conforme a teoria de Ihering, que se distancia do princípio da função social da propriedade e da posse. É o meio predominantemente utilizado por proprietários privados em situações de conflitos fundiários para reivindicar seu imóvel, ainda que esse tipo de lide traduza um conflito social multidimensional, distante do clássico modelo de interesses individuais contrapostos.

Questiono, então o tratamento privilegiado conferido à propriedade no ordenamento jurídico a partir da construção da noção de direitos reais e sobre posse e os seus reflexos na tutela processual. $\mathrm{O}$ direito à moradia, que também é direito fundamental, não tem o mesmo instrumental de proteção.

Os resultados aqui discutidos são fruto de uma pesquisa qualitativa, com revisão bibliográfica e pesquisa documental de processos judiciais. Analisei decisões judiciais de primeira instância em ações possessórias coletivas ajuizadas em varas cíveis em Fortaleza-CE, no período de 2010 a 2014, que reivindicavam a posse de imóveis privados.

Em tese, as decisões de primeira instância não representam com definitividade a interpretação do Poder Judiciário. Mas elas merecem destaque por serem a manifestação com maior e mais rápida possibilidade de intervenção na vida material das pessoas, em especial nos casos de conflitos fundiários veiculados por ações possessórias. Ademais, em diversas situações ela pode representar a solução única e definitiva dada ao caso.

Todas as decisões estudadas foram tomadas ainda sob a vigência do Código de Processo Civil de 1973, o que nos exige fazer reflexões comparativas com a sistemática do Código de Processo Civil de 2016. O Novo Código trouxe relevante mudança ao prever tratamento 


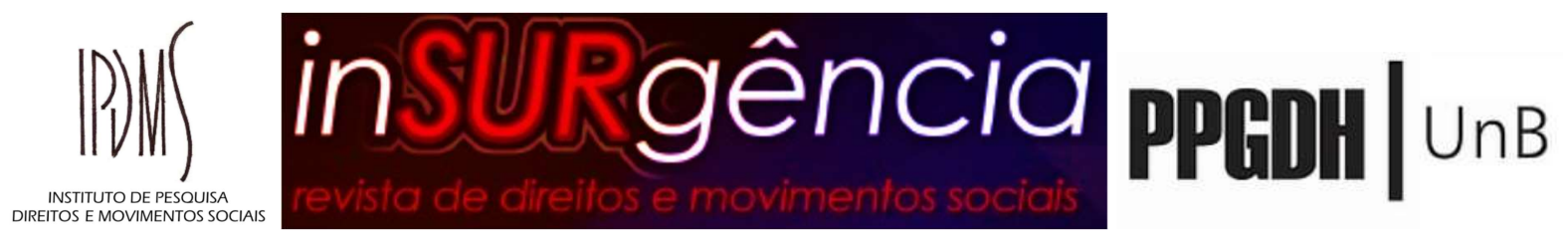

diferenciado para as ações possessórias coletivas, ainda que restrita às chamadas ações de força velha.

Ao passo que a hermenêutica, os métodos interpretativos, o papel do Poder Judiciário e as formas possíveis de controle democrático sobre eles estão na ordem do dia, é relevante discutir os limites e critérios para emissão de uma ordem de despejo forçado contra famílias em situação de alta vulnerabilidade social, contextualizando-as em relações sociais de poder e disputas ideológicas sobre o aparato legal e judicial.

\section{Conceituando conflito fundiário e despejo forçado}

Os conflitos fundiários urbanos são definidos pela Resolução 87/2009 do Conselho das Cidades, que recomenda ao Ministério das Cidades instituir a Política Nacional de Prevenção e Mediação de Conflitos Fundiários Urbanos, como:

[...] disputa pela posse ou propriedade de imóvel urbano, bem como impacto de empreendimentos públicos e privados, envolvendo famílias de baixa renda ou grupos sociais vulneráveis que necessitem ou demandem a proteção do Estado na garantia do direito humano à moradia e à cidade (BRASIL, 2009).

Uma das diretrizes da Política Nacional é o reconhecimento do caráter coletivo dos conflitos fundiários urbanos nos litígios pela posse e pela propriedade de imóvel urbano que envolvam famílias de baixa renda ou grupos sociais vulneráveis, e da necessidade de garantia do devido processo legal, do contraditório e da ampla defesa para todas as pessoas envolvidas.

A "Pesquisa sobre soluções alternativas para conflitos fundiários urbanos", partindo do mesmo conceito da Resolução 87/2009, propõe uma nova terminologia sobre os conflitos fundiários, classificando-os em "conflito fundiário em sentido amplo", de caráter eminente e fruto de um planejamento urbano excludente, e "em sentido estrito, que se dá num momento específico em que existem

[...] partes nomináveis, proprietários versus ocupantes, ou Poder Público versus particulares, com instauração de ações judiciais e iminência de remoção. São situações causadas por reintegração de posse ou por realização de grandes obras, empreendimentos ou por mero interesse econômico (DI SARNO; SAULE JUNIOR, 2013, p. 27). 


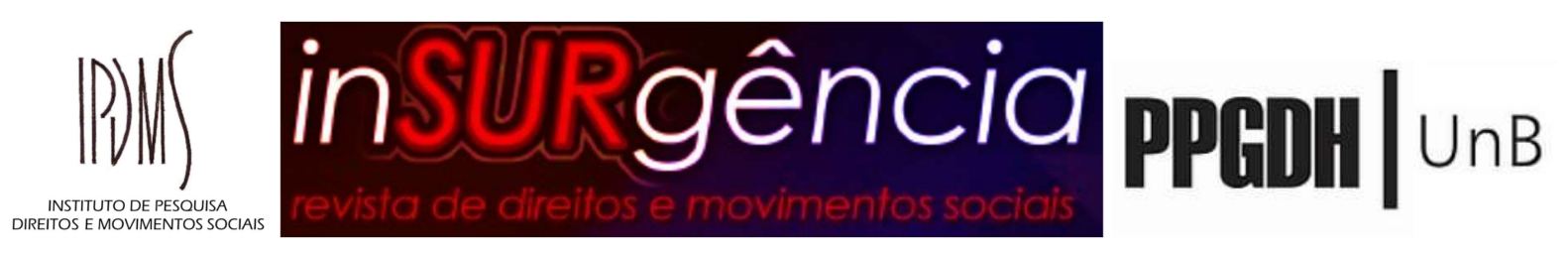

No direito brasileiro, o termo despejo é utilizado na Lei 8.245/1991 (Lei de Locações), como ação própria para que o proprietário retome o imóvel urbano diante do fim do contrato de locação. De acordo com a lei, a ação de despejo tem o rito ordinário. A liminar determinando a desocupação no prazo de 15 dias poderá ser dada sem ouvir o réu, desde que seja prestada caução e o fundamento exclusivo da ação estejam dentre as hipóteses previstas no $\operatorname{art} .59, \S^{\circ}{ }^{\circ}$ da Lei. Em algumas situações específicas da locação residencial, se o locatário concordar com a desocupação, poderá ter seis meses de prazo.

Nas ações possessórias, o termo legal utilizado não é despejo, mas sim a manutenção ou reintegração na posse. Mas, se a parte demandada tem a posse para fins de moradia, do ponto de vista jurídico e social não é simplesmente um ato de tomada da coisa que acontecerá, mas sim um despejo.

A importância de afirmar isso, sem que haja espaço para maior aprofundamento na discussão sobre outros ritos previstos ${ }^{3}$, é evidenciar a diferença de tratamento entre os procedimentos utilizados para o mesmo fato: perda da moradia pela perda da posse sobre o bem que a garante.

A realidade material do despejo só é reconhecida na legislação em algumas hipóteses, embora na prática, sejam mais amplas e provocadas pela lei. Em alguns casos, o despejo tem suas circunstâncias bem definidas, em outros não, como é o caso das reintegrações de posse contra ocupações urbanas.

Disso decorre que o ordenamento confere tratamento diferenciado à moradia a depender do título sobre o qual ela se fundamenta. Ou seja, a proteção não é para a moradia enquanto direito humano/fundamental e condição existencial que requer uma ligação da pessoa com um bem imóvel, mas sim para o título, de base legal ou contratual, que legitima essa relação.

Em âmbito internacional, existem definições e recomendações para o tratamento dos despejos forçados, a partir da proteção ao direito à moradia, reconhecido como direito humano pelo Pacto Internacional de Direitos, Econômicos, Sociais e Culturais (PIDESC), no artigo 11, item 1, promulgado pelo Decreto no 591, de 06 de julho de 1992.

O Comitê de Direitos Econômicos, Sociais e Culturais produziu os comentários gerais $\mathrm{n}^{\mathrm{o}}$ 4 e $\mathrm{n}^{\mathrm{o}} 7$ sobre o art. 11, item 1, que devem servir de referência aos Estados Partes signatários do Pacto. O Comentário Geral (CG) n $n^{\circ} 4$ determina que são componentes do direito humano à

\footnotetext{
${ }^{3}$ Além do procedimento de locação, outros decorrentes dos contratos habitacionais no âmbito do SFH ou outros tipos de contrato imobiliário para habitação, como alienação fiduciária e leasing.
} 


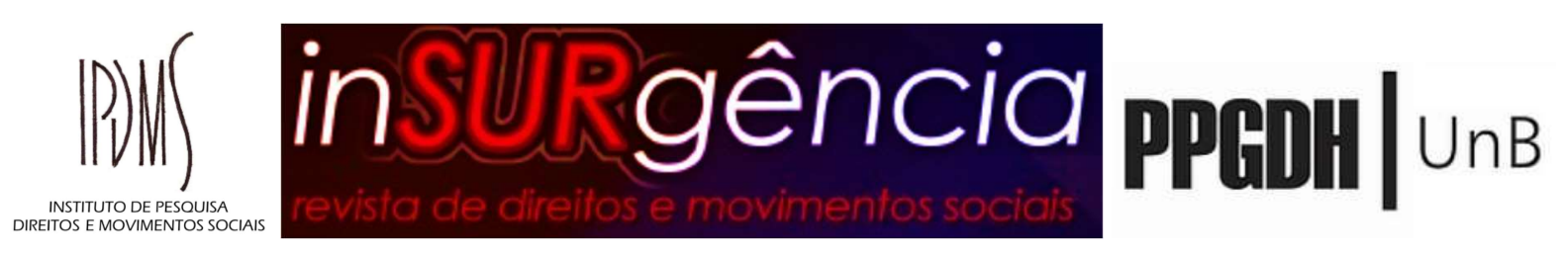

moradia adequada: a segurança jurídica da posse; a disponibilidade de serviços, materiais, facilidades e infraestrutura; o custo acessível; a habitabilidade; a acessibilidade; a localização; e a adequação cultural, sendo que cada um desses conceitos tem seu sentido explicado no comentário. Junto a esses componentes, Osório (2014) cita também elementos propostos por Miloon Kothari, ex-relator especial da ONU sobre Moradia Adequada, que devem ser considerados para avaliar a realização e extensão das violações desse direito humano, quais sejam: não privação da posse, informação e capacitação, participação na tomada de decisões, reassentamento, ambiente seguro, segurança (física) e privacidade.

O Comentário Geral $n^{\circ} 4$ do CDESC considerou que todas as pessoas devem possuir um grau de segurança da posse para lhes proteger contra os despejos forçados, os quais são prima facie incompatíveis com as exigências do PIDESC.

De acordo com Osório (2014), o CG n 4 indicou também que os despejos forçados só podem ser realizados em conformidade com os princípios do direito internacional dos direitos humanos e em circunstâncias excepcionais, que devem ser definidas pelas legislações nacionais de forma a diferenciar os casos de despejo de quem reside pacificamente num lugar e de quem descumpre injustificadamente suas obrigações legais ou contratuais em relação a determinado imóvel. Como exemplo de situações excepcionais, temos a ocorrência de racismo ou atos discriminatórios, ataques de um inquilino contra outros, persistência da falta de aluguel apesar de comprovada a capacidade de pagamento, ocupação ilegal de propriedade habitada.

$\mathrm{O} C G n^{\circ} 7$ recomenda aos Estados-Parte que tomem medidas preventivas para que despejos forçados e remoções não ocorram e esclarece as implicações da sua prática em relação às obrigações contraídas no PIDESC, tendo em vista a significativa quantidade de denúncias recebidas, inclusive com violação aos deveres dos Estados-Parte. O Comentário resgata iniciativas em âmbito internacional, como a Habitat I (1976), a Estratégia Global para Habitação para o ano 2000 (1988), a Agenda 21 (1992), a Agenda Habitat (1996), que condenam a prática de despejo forçado, mas que deixavam em aberto uma das questões mais críticas, ou seja, as circunstâncias em que os despejos forçados são admissíveis e os tipos de proteção necessários para garantir o respeito ao PIDESC. Assim, os despejos forçados são definidos como:

[...] a remoção permanente ou temporária de pessoas, famílias e/ou comunidades de suas moradias e/ou das terras que ocupam, contra a sua vontade e sem oferecer-lhes meios apropriados de proteção legal ou de outra índole nem permiti-lhes seu acesso a elas. Entretanto, a proibição de despejos forçados não se aplica àqueles efetuados 


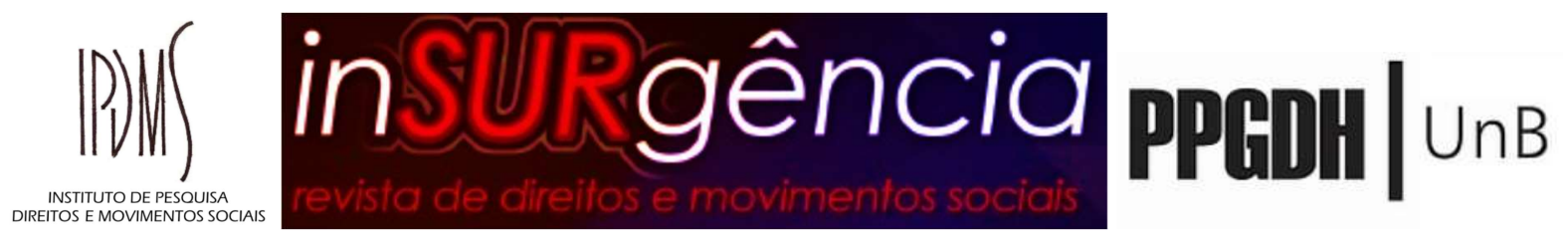

legalmente e em acordo com as disposições dos Pactos Internacionais de Direitos Humanos (OSÓRIO, 2014, p. 55-56).

Entre outras questões, o CG n 07 reconhece, no parágrafo 4, que os despejos forçados podem resultar na violação de direitos civis e políticos e também ao direito à vida, à segurança da pessoa, a não interferência na privacidade, família e lar, bem como ao direito de gozo pacífico dos bens. Diz ainda, no parágrafo 12, que os despejos forçados e as demolições de casas como medidas punitivas são incompatíveis com as normas do PIDESC, e ressalta as obrigações da Convenção de Genebra de 1949 e do respectivo Protocolo Adicional de 1977, relativos às proibições de deslocamento da população civil e destruição da propriedade privada, tendo em vista o modo como eles se relacionam com a prática dos despejos forçados.

Osório (2014) explica que, para o CDESC, os elementos que compõem o despejo são a determinação por decisões, legislação ou política (ainda que por omissão) de Estado; a presença invariável de 'força' ou coerção; o planejamento prévio à implementação; a possibilidade de afetarem tanto indivíduos quanto grupos.

A autora esclarece que o parágrafo 11 do $\mathrm{CG} \mathrm{n}^{\mathrm{o}} 07$ fala sobre possibilidades de justificação de despejo, como a falta de pagamento de aluguel e danos causados a uma propriedade alugada ou concedida sem causa justificada. Afirma, além disso, que o parágrafo 14 do CG n ${ }^{\circ} 07$ diz que se o despejo está justificado, ele deve ser implementado conforme as normas internacionais de direitos humanos e respeitar os princípios gerais de razão e proporcionalidade, devendo ser considerado o disposto no $\mathrm{CG} \mathrm{n}^{\circ} 16$ do Comitê de Direitos Humanos, relativo ao art. 17 do PIDESC, que indica que a ingerência no domicílio só deve ocorrer nos casos previstos em lei. No CG n ${ }^{\circ} 16$, o Comitê indicou que a lei interna deve estar em conformidade com o Pacto e que deve especificar com detalhes as circunstâncias precisas em que se podem autorizar as ingerências.

Além disso, o parágrafo 13 do CG n ${ }^{\circ} 07$ diz que os Estados devem evitar os despejos forçados, em especial os que envolvem grandes grupos de pessoas, quando devem ser exploradas alternativas viáveis junto a população afetada, de modo a evitar ou, pelo menos, minimizar o uso da força. Já o parágrafo 16 diz que

[...] os despejos não podem resultar na constituição de indivíduos sem casa ou vulneráveis a violações de outros direitos humanos. No caso da pessoa afetada ser incapaz de prover por si mesma uma alternativa, o Estado deve adotar todas as medidas apropriadas, ao máximo de seus recursos disponíveis, para assegurar que uma moradia alternativa adequada, reassentamento ou acesso à terra produtiva estejam disponíveis (OSÓRIO, 2014, p. 58). 


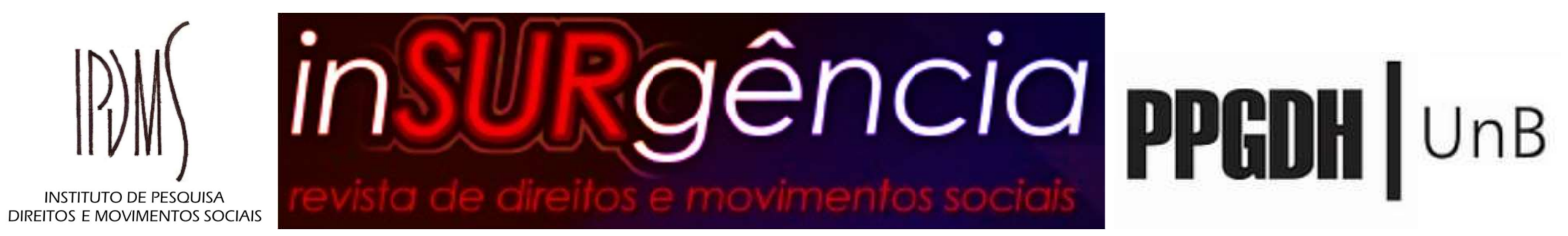

Percebe-se que há uma adequação entre a noção de despejo forçado que vem sendo construída internacionalmente e o que ocorre efetivamente no curso dos processos. No entanto, a quase unanimidade das decisões que concedem a liminar de despejo não oferecem a chance cantada por Adoniran Barbosa, que intitulam esse trabalho. Nem 10 dias e nem mesmo horário comercial. A maior parte dos despejos é feita sem a defesa dos réus e são iniciados às $6 \mathrm{~h}$ da manhã, a fim de dificultar as chances de resistência à medida.

O Código de Processo Civil de 2016 trouxe inovações em relação ao procedimento possessório coletivo, quando se tratar de ações de força velha, ou seja, ajuizadas após 1 ano e 1 dia após a alegada data de esbulho.

De acordo com o art. 565, nestes casos, o juiz deve designar audiência de mediação, antes de apreciar o pedido liminar. A mediação também deve ser realizada novamente se, concedida a medida, ela não for executada no prazo de 1 ano (art. $565, \S 1^{\circ}$ ). São previstas ainda a necessidade de intimação do Ministério Público e da Defensoria Pública, quando houver parte beneficiária da justiça gratuita (art. $565, \S 2^{\circ}$ ). Para a audiência, também podem ser intimadas os órgãos responsáveis pela política agrária e pela política urbana da União, de Estado ou do Distrito Federal e de Município, onde se situe a área objeto do litígio, a fim de se manifestarem sobre seu interesse no processo e sobre a existência de possibilidade de solução para o conflito possessório (art. $565, \S 4^{\circ}$ ). O juiz também poderá comparecer à área objeto do litígio quando sua presença se fizer necessária à efetivação da tutela jurisdicional (art. 565, $\S 3^{\circ}$ ).

Todas essas mudanças representam avanços inegáveis e constituem um redimensionamento jurídico político do conflito possessório enquanto conflito fundiário, ou seja, a disputa pela posse não é apenas a um instrumento de proteção à propriedade, mas expressão da luta por moradia e pelo acesso à terra urbana, que dependem de políticas públicas, sob a qual o Poder Judiciário tem atuação.

A tentativa de mediação como alternativa ao despejo por medida liminar, em situações minimamente consolidadas de ocupação, mitigam a injustiça e desigualdade do sistema, privilegiando o direito à moradia em relação ao direito de propriedade. Todavia, sua aplicação obrigatória é restrita às ações de força velha, o que não resolveria, por exemplo, os problemas identificados nos casos estudados nessa pesquisa e que serão detalhados a seguir. 


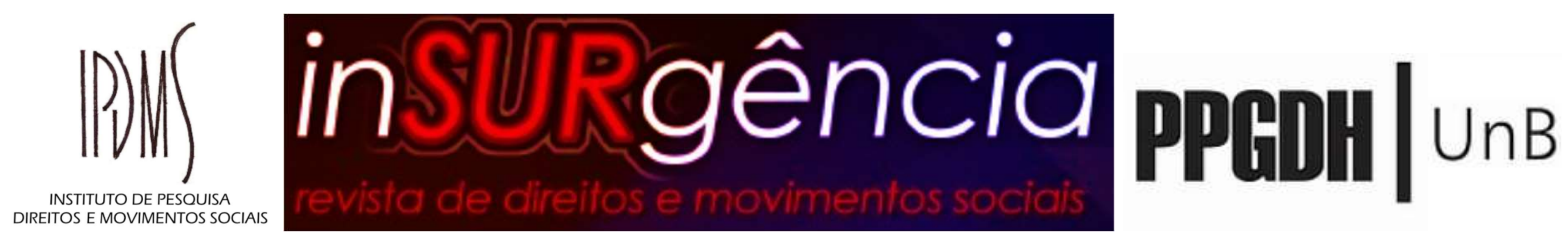

\section{Metodologia de análise e panorama dos casos estudados}

A falta de sistematização de dados locais ou nacionais sobre os conflitos fundiários dificultam a sua investigação. Por isso, o estudo de caso é rotineiramente adotado como método de pesquisa. Não escolhi um caso específico porque o objetivo não era me aprofundar na pluralidade de dimensões que ele tem, mas sim focar na atuação jurisdicional de um modo mais abrangente, ainda que sem a pretensão de produzir dados estatísticos ou de caráter totalizante.

Para alcançar um universo amplo sobre a realidade do tratamento judicial aos conflitos fundiários na cidade de Fortaleza, foi solicitada, por oficio, à Diretoria do Fórum Clóvis Beviláqua, a relação de ações possessórias distribuídas no período entre 2010 e 2014 nas varas cíveis com a classe 1707 (Reintegração/Manutenção de Posse) e o Assunto 10445 (Esbulho/turbação/ameaça).

A relação ofereceu um total de 453 ações judiciais ${ }^{4}$. Todos os processos foram consultados digitalmente, e foi possível excluir rapidamente dezenas deles, que tratavam sobre arrendamento mercantil de automóvel. Também foram excluídas as ações possessórias de caráter individual, o que era possível perceber pela qualificação das partes, descrição do imóvel, explicação na petição inicial sobre a motivação do conflito, entre outros.

Os critérios utilizados para classificar o caso como conflito fundiário foram a sua adequação ao conceito trazido pela Resolução 87/2009: o polo passivo da ação (réus), formado por uma coletividade de pessoas de baixa renda e o indicativo de que a ocupação é feita para fins de moradia ${ }^{5}$. Chegamos, então, ao total de 27 casos.

Nesse caminho, a pesquisa se aproxima da proposta de Santos (1983), chamada de "método do caso alargado", desenvolvido pela antropologia cultural e social, pelo qual, ao invés de fixar uma quantidade de casos adequada, adota-se um número limitado de casos em que se condensam vetores estruturais das economias interacionais dos diferentes participantes de uma

\footnotetext{
${ }^{4}$ A pesquisa feita pelo setor de informática não se restringiu ao assunto solicitado ("esbulho/turbação/ameaça"). Tanto a classe quanto o assunto são definidos pela pessoa que protocola a petição inicial no sistema, podendo também ser modificada por iniciativa do juiz. Embora a maioria das ações possessórias listadas tenha o assunto "esbulho/turbação/ameaça", que seria o mais apropriado, não há uma padronização, e outros assuntos podem ser escolhidos, como por exemplo "posse", "liminar" ou "antecipação de tutela/tutela específica". Esses assuntos também integraram os filtros de pesquisa feitos pelo setor de informática e permitiu maior abrangência dos casos. ${ }^{5} \mathrm{O}$ perfil do autor da ação não foi utilizado para caracterizar a ação como conflito fundiário ou não. Tanto que há casos em que o autor não se reivindica proprietário, mas apenas possuidor, e também casos em que o imóvel em litígio não é uma grande propriedade vazia. Em algumas situações, a ausência do caráter de conflito fundiário era facilmente perceptível pela narrativa da petição inicial. Em outras, foi necessário refinar a pesquisa, sendo necessário analisar mais detalhes do processo, como termos de audiência, certidão do oficial de justiça, contestações, ou mesmo fazer uma leitura integral dos autos.
} 


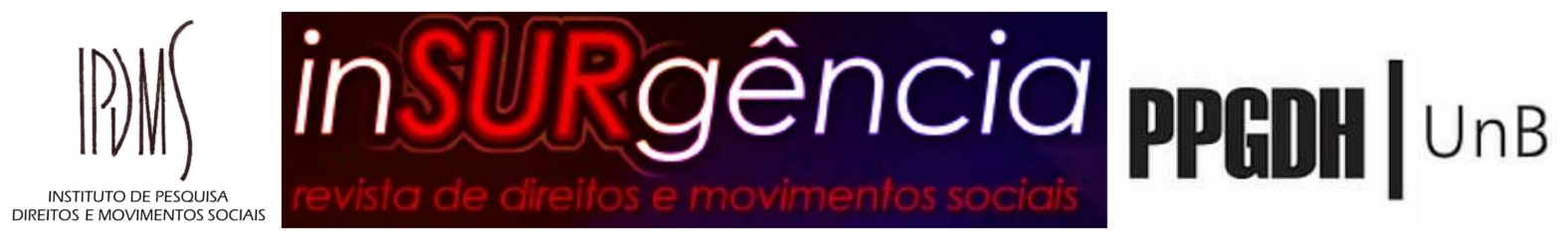

prática setorial. Os casos devem ser analisados em detalhes, pela sua complexidade e exemplaridade.

Entre os 27 casos estudados, em 15 foi concedida a medida liminar de reintegração/manutenção de posse, sendo eles o foco deste trabalho.

Segue abaixo uma tabela indicativa dos dados processuais básicos desses 15 casos, bem como a referência a eles adotada, para facilitar a comunicação. A tabela apresenta apenas os casos em que foi concedida a liminar, mantendo a numeração original que considera o universo total.

\begin{tabular}{|c|c|}
\hline $\begin{array}{l}\text { Caso 01: Terreno na Rua Pintor Antonio } \\
\text { Bandeira, no loteamento Praia Antônio } \\
\text { Diogo, bairro Praia do Futuro. Processo no } \\
\text { 0161937-23.2013.8.06.0001/ } 4^{\mathrm{a}} \text { Vara/ } \\
\text { Protocolo: } 13.05 .2013 \text {. Liminar concedida } \\
\text { em } 26 \text { de julho de } 2013 \text {. }\end{array}$ & $\begin{array}{l}\text { Caso 14: Imóvel na Av. Padre Antônio } \\
\text { Tomás, 2330-2714, Dunas (Loteamento } \\
\text { Antonio Diogo). Processo n }{ }^{o} \text { 0543161- } \\
\text { 41.2012.8.06.0001/ } 26^{\text {a Vara/ }} \\
\text { Protocolo:18.01.2012; Liminar concedida } \\
\text { em } 23 \text { de janeiro de } 2012\end{array}$ \\
\hline 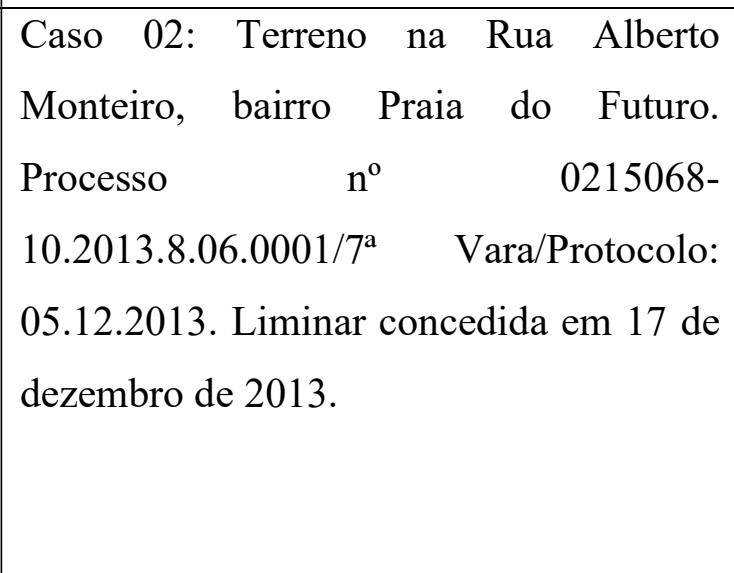 & $\begin{array}{l}\text { Caso 15: imóvel localizado na Rua } \\
\text { Luciano Alves no loteamento Parque } \\
\text { Santa Filomena, constituído pelos lotes } \\
\text { 19, 20, } 24 \text { e 25, da Quadra 55, Bairro } \\
\text { Jangurussu. Processo no } 0140401- \\
\text { 53.2013.8060001/ } 18^{\text {a }} \text { Vara/ Protocolo: } \\
\text { 14.02.2013. Liminar concedida em } 20 \text { de } \\
\text { maio de 2013. }\end{array}$ \\
\hline 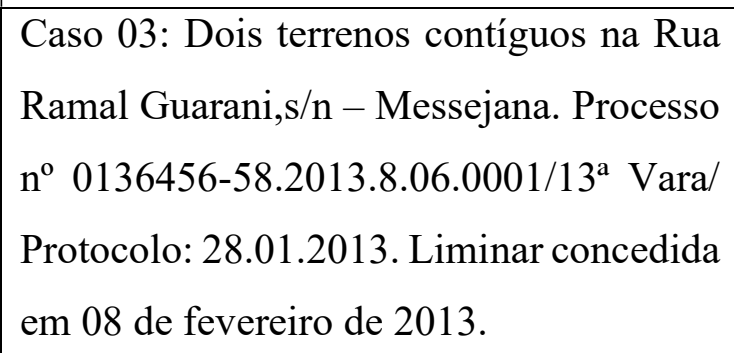 & $\begin{array}{l}\text { Caso 16: "Oito casinhas" na Rua das } \\
\text { Jaqueiras, 380, Mondubim. Processo no } \\
\text { 0147024-36.2013.8.06.0001/ } 15^{\mathrm{a}} \text { Vara/ } \\
\text { Protocolo:13/03/2013/ Liminar concedida } \\
\text { em } 14 \text { de março de 2013. }\end{array}$ \\
\hline
\end{tabular}




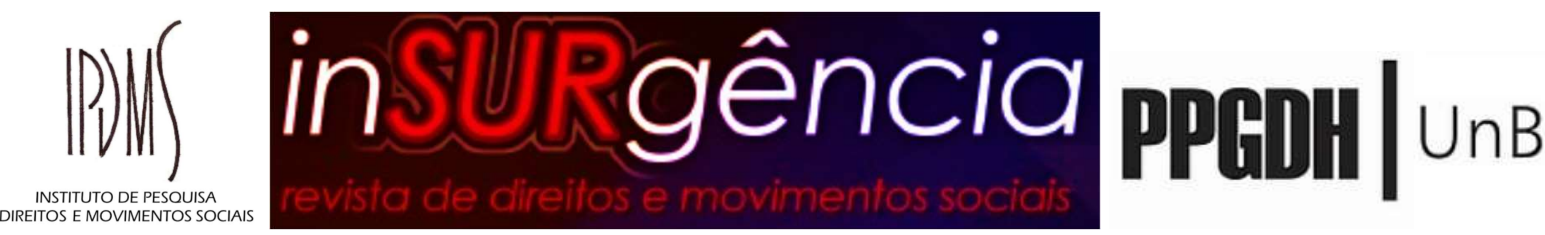

\begin{tabular}{|c|c|}
\hline $\begin{array}{l}\text { Caso 04: Área verde de parte do } \\
\text { loteamento Terranova, entre as Ruas } \\
\text { Daura e Av. Hugo Bezerra, s/n, Barroso. } \\
\text { Processo no 0141894-65.2013.8.06.0001/ } \\
1^{\text {a }} \text { Vara/Protocolo: 20.02.2013. Liminar } \\
\text { concedida em } 04 \text { de março de 2013. }\end{array}$ & $\begin{array}{l}\text { Caso 17: Área de terra que perfaz um total } \\
\text { de } 44.901,80 \mathrm{~m}^{2} \text {, do Loteamento } \\
\text { denominado Parque Messejana, imóvel } \\
\text { este que faz frente (lado leste), para a Rua } \\
\text { Luiz Francisco Xavier. Processo } \mathrm{n}^{\mathrm{o}} \\
0161772-73.2013 .8 .06 .0001 / 29^{\mathrm{a}} \text { Vara } \\
\text { Protocolo:13.05.2013 Liminar concedida } \\
\text { em } 22 \text { de agosto de } 2013 \text {. }\end{array}$ \\
\hline 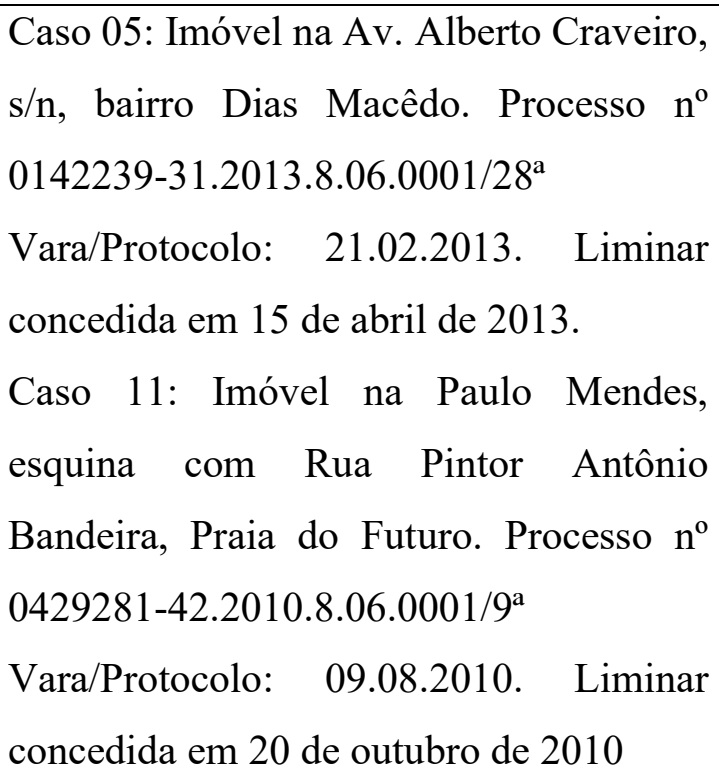 & $\begin{array}{l}\text { Caso 18: Um imóvel com } 2.030,46 \mathrm{~m}^{2} \text { de } \\
\text { área, situado frente para a Rua Matos } \\
\text { Vasconcelos } \mathrm{s} / \mathrm{n}^{\circ} \mathrm{e} \text { fundos para a Av. José } \\
\text { Bastos,área de futura Via do Eixo } \\
\text { Ferroviário) e mais dois imóveis na Av. } \\
\text { José Bastos. Processo } \mathrm{n}^{\mathrm{o}} 0167144- \\
\text { 03.2013.8.06.0001/ } 5^{\mathrm{a}} \text { Vara/ Protocolo: } \\
\text { 03.06.2013. Liminar concedida em } 04 \text { de } \\
\text { junho de 2013. }\end{array}$ \\
\hline 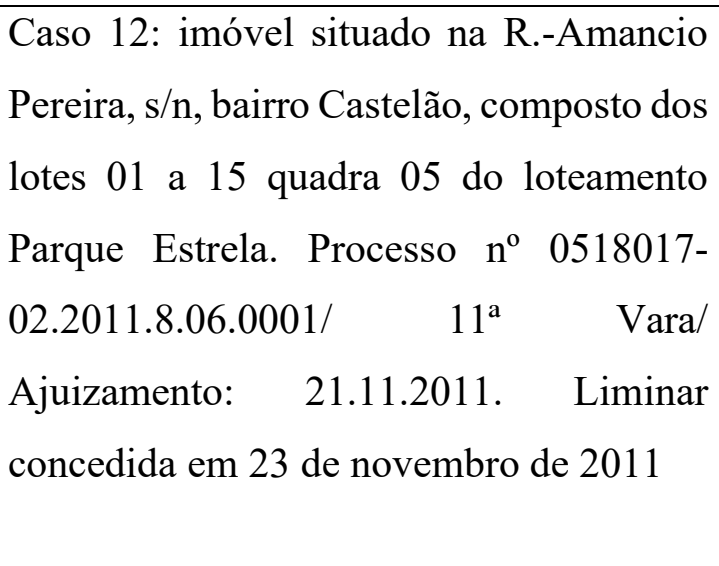 & $\begin{array}{l}\text { Caso 19: Imóvel no Loteamento Parque } \\
\text { Água Fria, nas esquinas das Ruas Coronel } \\
\text { Olegário Memoria, Avenida Evilásio } \\
\text { Almeida Miranda (antiga Av. Lagoa } \\
\text { Redonda) e Rua Sapiranga. Processo n } \\
\text { 0145499-19.2013.8.06.0001/ } \\
\text { Vara/Protocolo: 06.03.2013. Liminar } \\
\text { concedida. }\end{array}$ \\
\hline $\begin{array}{l}\text { Caso 13: Imóvel de } 10.000 \mathrm{~m}^{2} \text { no Bairro } \\
\text { José Walter com a frente para a Av.I. } \\
\text { Processo } \\
\text { 07.2012.8.06.0001/18 }{ }^{\mathrm{a}} \text { Vara/ Protocolo: }\end{array}$ & $\begin{array}{l}\text { Caso 20: Imóvel na Avenida Osório de } \\
\text { Paiva no bairro Siqueira composto por três } \\
\text { matrículas que totaliza uma área de } \\
15.945,33 \mathrm{~m} 2 \text {. Processo } \mathrm{n}^{\circ} 0183089-\end{array}$ \\
\hline
\end{tabular}




\begin{tabular}{|c|c|}
\hline $\begin{array}{l}\text { 22.11.2012. Liminar concedida em } 23 \text { de } \\
\text { novembro de } 2012\end{array}$ & $\begin{array}{l}\text { 30.2013.8.06.000/9a Vara/ Distribuição: } \\
\text { 05.08.2013. Liminar concedida em } 12 \text { de } \\
\text { agosto de } 2013 \text {. }\end{array}$ \\
\hline
\end{tabular}

Entre os 15 casos em que foi concedida a liminar, em nenhum houve a defesa prévia dos réus $^{6}$, em 11 foi autorizado o uso de força policial na própria decisão sobre a liminar ${ }^{7}$, e em 07 , a ordem de arrombamento. ${ }^{8}$ No caso 14 , a força policial e a ordem de arrombamento foram admitidas pelo juiz após certidão do oficial de justiça que solicitava essas providências, tendo em vista estarem no terreno mais de 100 pessoas. Nessa certidão não há informação sobre intimação ou qualquer contato com os demandados que justificasse o uso prioritário da força. No caso 04, o uso de força policial e de ordem de arrombamento foi também autorizado após pedido da parte autora, que informava que os réus não queriam cumprir a decisão.

Nos casos 01 e 04, a liminar determinou também o desfazimento de construções; nos casos 01, 04 e 13 foi estabelecida multa em caso de descumprimento da decisão, mesmo que os autos demonstrassem que a condição econômica dos réus não permitiria o seu pagamento. Nos casos 05 e 13 foi autorizado o cumprimento fora do horário regular dos atos processuais (06h às $20 \mathrm{~h}$ ), sendo que no primeiro foi autorizada a exceção do art. $172, \S 2^{\circ 9}$, do CPC/1973; no segundo, o cumprimento aos finais de semana. Apenas nos casos 04 e 18 foram concedidos um prazo de 48 horas para a desocupação antes do cumprimento forçado.

Nos dois casos em que houve sentença de procedência (casos 01 e 02), também foi determinado o seu cumprimento com uso de força policial. Dessa forma, dos 15 casos em que foi autorizado o despejo, em 14 a força policial foi autorizada expressamente em algum momento.

O despejo foi efetuado em 13 casos. ${ }^{10}$ Dentre eles, no caso 04, o autor informou que houve a desocupação voluntária; no caso 05 , foi informado que houve um despejo anterior, feito pela

\footnotetext{
${ }^{6}$ Dos 15 casos, apenas no caso 19 foi dada a oportunidade de os réus se manifestarem antes, o que não aconteceu mesmo com a citação certificada por oficial de justiça.

${ }^{7}$ Casos $01,03,05,11,12,13,15,16,17,18,19,20$.

${ }^{8}$ Considerando o marco temporal da pesquisa, até março de 2016. Casos 01, 05, 11, 13, $16,19$.

${ }^{9} \mathrm{CPC} / 1973$. "Art. 172 [...]. $\S 2^{\circ} \mathrm{A}$ citação e a penhora poderão, em casos excepcionais, e mediante autorização expressa do juiz, realizar-se em domingos e feriados, ou nos dias úteis, fora do horário estabelecido neste artigo, observado o disposto no art. $5^{\circ}$, inciso $\mathrm{Xl}$, da Constituição Federal. (Redação dada pela Lei $\mathrm{n}^{\circ}$ 8.952, de 13.12.1994)".

${ }^{10}$ Casos $01,02,03,04,05,11,12,13,14,16,17,18$ e 20.
} 


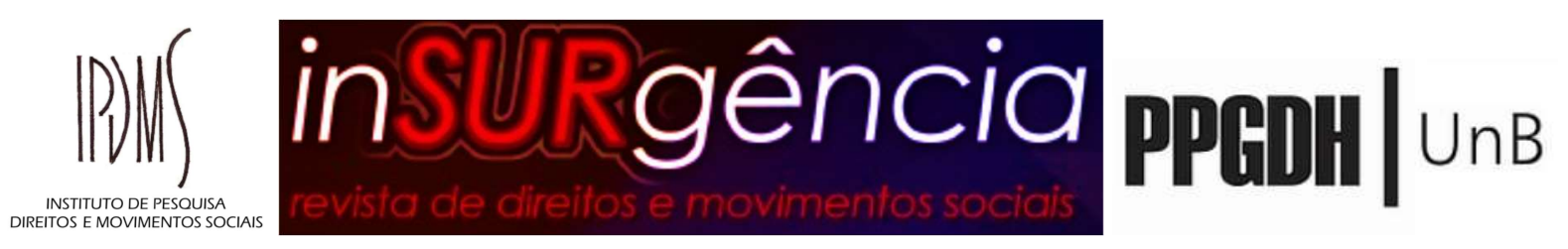

Guarda Municipal, e depois desocupação voluntária; e no caso 18, foi concedido, na decisão liminar, um prazo de $48 \mathrm{~h}$ para desocupação voluntária, que foi efetivada. Não houve cumprimento nos casos 15 e 19.

O uso de força policial, a ordem de arrombamento, o cumprimento em horários diferenciados e a demolição das construções são admitidos nas decisões judiciais como uma consequência normal, quase natural, do mandado de reintegração de posse. Não há em nenhum caso fundamentação específica para a utilização desses recursos. No máximo, há a recomendação de que sejam preservadas as "devidas cautelas" no uso da força ou a ressalva de que esta deve ser utilizada apenas "se for necessária". Em alguns casos, inclusive, parece ficar em aberta a possibilidade da utilização da força policial, como no caso 18 , no qual ao final da decisão consta que: "O mandado de reintegração deve ser cumprido com respeito e moderação, mesmo que em caso de se fazer necessário o uso de força pública" (fls. 74), ou no caso 20: "O uso da força policial, caso necessário, será exercida segundo a prudência e cautela que o caso requerer" (fls. 59).

Na prática, o procedimento do despejo dependerá do modus operandi do oficial de justiça e da força policial que comandar a operação. Ao juiz cabe a autorização, mas um controle efetivo do ato dificilmente existe. A Secretaria de Segurança Pública e Defesa Social, por meio da Polícia Militar, tem trâmites, métodos de planejamento e atuação internos que, em todos os casos analisados, são alheios ao processo e ao controle jurisdicional, pois não há neles nenhum registro sobre isso.

Até mesmo o procedimento sobre como a polícia é acionada para acompanhar o despejo não é claro em diversos casos, não havendo registro nos autos sobre isso. Em algumas situações, há remessa de ofício para instituição solicitando o apoio, o que o torna menos informal, mas em outros há apenas a informação na certidão do oficial de justiça de que a ação de despejo foi acompanhada pela polícia militar. Em um caso, o oficial certifica que buscou a polícia militar e lá foi informado de que o apoio policial deveria ser solicitado para a Secretaria de Segurança Pública.

Considerando-se a forte mobilização administrativa para o ato de despejo, seria necessária uma maior clareza sobre os mecanismos de participação da Polícia Militar, tendo em vista os princípios constitucionais da Administração Pública e a possibilidade de controle jurisdicional e social sobre os seus atos. Em geral, algumas dezenas de policiais atuam no despejo com diversos carros e equipamentos, inclusive com a utilização de cavalaria e/ou canil. 


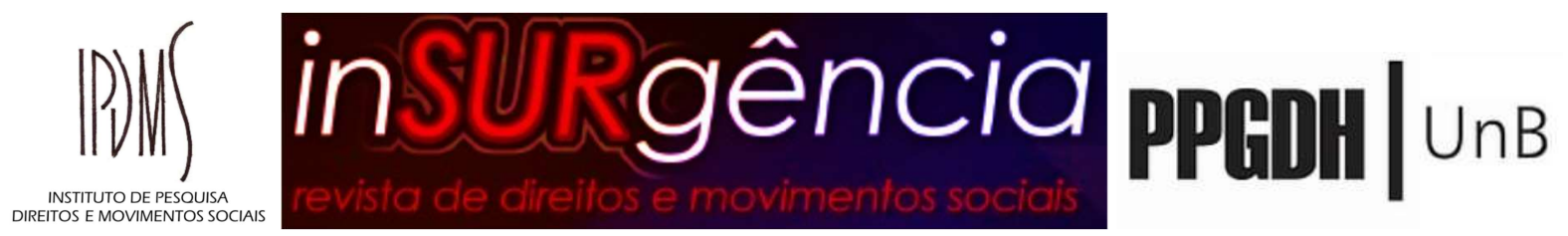

Sem um diálogo interinstitucional, os reclames de prudência contidos na decisão são vazios, pois o juiz não participa e desconhece que medidas podem ser tomadas para que hajam "as devidas cautelas" ou qual é "a força estritamente necessária" para cumprimento da decisão. A distância do juiz em relação ao conflito gera uma verdadeira desresponsabilização do Judiciário sobre as suas próprias determinações. É comum ouvir dos policiais, inclusive os que assumem posição de comando na operação, que eles assumem sozinhos a responsabilidade social sobre o despejo, enquanto estão apenas cumprindo uma ordem judicial. É o famoso "se eu pudesse, não estava aqui”.

Assim, as operações assumem uma forma militar em que a margem de negociação é pequena, e na qual os ocupantes e apoiadores são considerados inimigos, devendo ser pegos de surpresa e sem possibilidade de oferecer oposição. Aliás, se existir qualquer tipo de oposição, ela é reprimida com a ostensividade; se essa não é suficiente, faz-se uso de medidas de violência, inclusive com armamento não letal.

\section{Tutela possessória: a proteção do direito à moradia $X$ proteção ao direito de propriedade}

Como bem explica Grossi (2006), a propriedade é sobretudo mentalidade, entendida essa como um complexo de valores que circulam e se constituem como um tecido conectivo de determinado espaço e tempo. E ao contrário do que possa se propugnar, a mentalidade não está isolada no âmbito político, mas se manifesta sobretudo no âmbito jurídico

[...] com um olhar prevalentemente sincrônico, já que os valores tendem a permear a globalidade da experiência, com a atitude prevalentemente sistemática, já que os valores tendem permanecer e a cristalizar-se, o jurista se sente à vontade - quase em casa, dir-se-ia - no terreno das mentalidades; é aí que o jurídico tem suas raízes (GROSSI, 2006, p. 30).

Diz Grossi (2006) que mais do que qualquer instituto jurídico, a propriedade está ligada às mentalidades, porque ela não está associada apenas às formas, mas a uma visão do homem no mundo e também a uma ideologia, dado a sua vinculação aos interesses vitais de indivíduos e classes sociais. Por isso, a ordem fundiária de um determinado momento histórico é muito mais aquilo que circula invisivelmente do que os sinais sensíveis da paisagem.

Em tese, os procedimentos especiais, como o das ações possessórias, são criados em função da especificidade do bem da vida que tutelam, cuja proteção não seria suficiente ou 


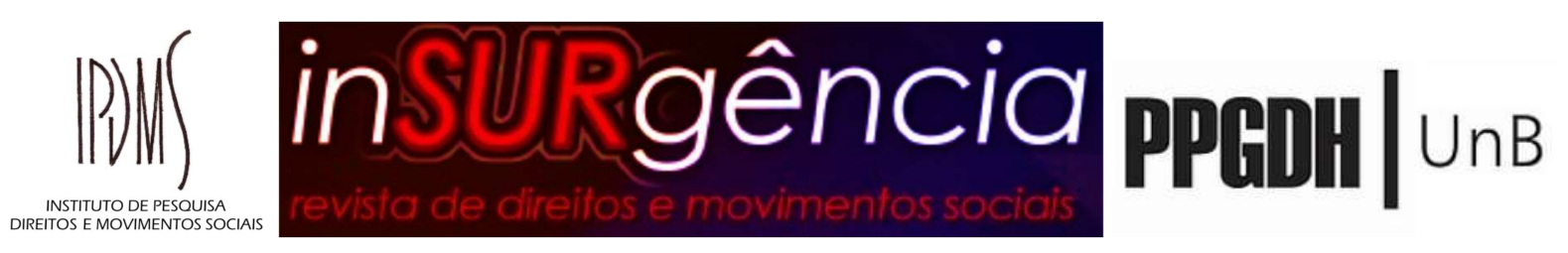

adequada dentro no modelo ordinário do processo civil. Fatores políticos e ideológicos atuam na criação desses procedimentos, oferecendo, em algumas situações, maior celeridade e criando meios que elastecem as prerrogativas de uma das partes em face de outras (VIANA, 2005).

O procedimento das ações possessórias está recheado de especificidades que garantem a proteção à propriedade nas mais diferentes situações. Isso se justificado por duas construções jurídicas dominantes no nosso sistema jurídico: a) a ideia de autonomia da posse como instrumento de facilitação de proteção ao direito de propriedade b) a ideia de que a propriedade enquanto direito real.

\subsection{A posse como instrumento de proteção da propriedade}

Explica a doutrina (GOMES, 2008; RIZZARDO, 2007) que o Código Civil Brasileiro adotou de forma predominante a teoria objetiva da posse de Ihering, que se expressa, em especial, no art. 1.196: "Considera-se possuidor todo aquele que tem de fato o exercício, pleno ou não, de algum dos poderes inerentes à propriedade", o qual traz um conceito de possuidor, mas não de posse. A teoria também se expressa no art. 1.204, que diz: "Adquire-se a posse desde o momento em que se torna possível o exercício, em nome próprio, de qualquer dos poderes inerentes à propriedade".

Ihering (2005) sustenta sua teoria na elaboração teórica e prática do Direito Romano. Para ele, a posse representa o poder de fato e a propriedade o poder direito sobre a coisa; elas são autônomas no sentido de que nem sempre estão reunidas no proprietário. Mas isso só ocorre em duas situações: ou o proprietário transfere a posse para outra pessoa, o que faz com que a posse seja justa, ou a coisa é retirada do proprietário contra a sua vontade, quando a posse é injusta. Assim, o proprietário tem o direito de posse, o jus possidendi, em que ela existe como uma relação jurídica decorrente do direito de propriedade, não existe apenas como um fato, como ocorre no jus possessionis.

Ou seja, a autonomia da posse não a desvincula da propriedade, mas existe para ampliar as possibilidades de sua exploração econômica. Por isso mesmo a posse é definida por Ihering (2005, p.13) como condição do aproveitamento econômico do bem, “[...] é um meio para alcançar um fim”, e por isso, sem ela, a propriedade de nada serve.

Portanto a proteção possessória é, em sua essência, “[...] um complemento indispensável da propriedade" (IHERING, 2005, p.30). Esclarece o romanista que o poder de fato não está 


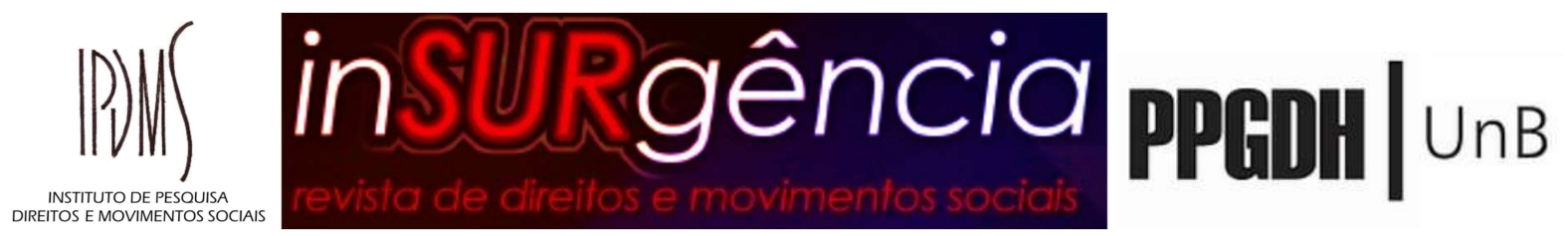

relacionado ao poder físico sobre o bem, mas à exteriorização da propriedade: “A segurança do possuidor não se baseia em se acharem em situação de excluir a ação de pessoas estranhas (Savigny), mas em proibir a lei esta ação: apoia-se, pois, não num obstáculo físico, e sim em um jurídico" (IHERING, 2005, p.50).

Segundo Ihering (2005), o motivo legislativo para a proteção da posse não é nem o interesse da paz e da ordem pública, como diria Savigny, nem a atenção à vontade da pessoa, nem a defesa do possuidor enquanto tal, mas sim proteger o proprietário e facilitar e aliviar a proteção da propriedade, porque a propriedade no seu estado normal tem na posse a sua exterioridade e visibilidade, mais fácil que a comprovação da propriedade, em especial em relação aos bens móveis.

É relevante lembrar que atualmente a prova da propriedade imóvel é taxativamente feita pelo registro oficial. Ao tempo dessa construção teórica, o sistema de registros públicos não estava consolidado, mas a doutrina mantém, anacronicamente, o discurso da prova da propriedade como "prova diabólica", quando em relação aos bens imóveis, a posse é considerada existente pela simples prova da propriedade (GOMES, P.O, 2016).

Nos casos estudados nessa pesquisa em que houve a concessão da medida liminar, de forma geral, a posse foi considerada existente com base na comprovação da propriedade e o esbulho com base na ocupação do imóvel, como se percebe pelos trechos:

Em primeira análise, pelo que dos autos se sobressaem, os autores demonstraram os requisitos necessários e indispensáveis a concessão da liminar pleiteada. Com efeito, pela documentação acostada aos autos, os autores comprovaram a propriedade dos imóveis esbulhados e a invasão dos mesmos (fls. 73, caso 18).

Sabe-se que a fumaça do bom direito são (sic) justamente os indícios suficientes da plausibilidade do direito pleiteado. In casu, entendo que a documentação acostada à peça vestibular consubstancia as alegações autorais, visto que demonstra a propriedade e a invasão relatada (fls. 58 , caso 20 , grifos no original).

Analisando detidamente os autos, vê-se que a autora provou sua posse mediante o registro do imóvel matriculado no $6^{\circ}$ Ofício de Registro de Imóvel, restando límido a sua posse, bem como o esbulho ocorrido em 16 de novembro de 2012, através do Boletim de Ocorrência acostado aos autos, mostraram com clareza que os invasores tomaram a posse do imóvel descrito e caracterizado na exordial [...]. Assim, resta cristalino que a posse dos requeridos é injusta diante da ofensa ao art.1.200 do Código Civil Brasileiro, restando incontroverso nos autos que cortaram as cercas que delimitavam o terreno nas escondidas, na calada da noite (fls. 45, caso 13).

Analisando os autos, vê-se que, os autores provaram sua posse com a documentação carreada com a exordial e, os fatos ali articulados, mostraram com clareza que os requeridos encontram-se residindo no imóvel, sem quererem desocupá-lo. Depreendese dos autos que os demandantes estão sofrendo prejuízos, uma vez que possuem um imóvel, sem poder usá-lo, sendo que para tanto, trouxeram para os autos, cópia de 


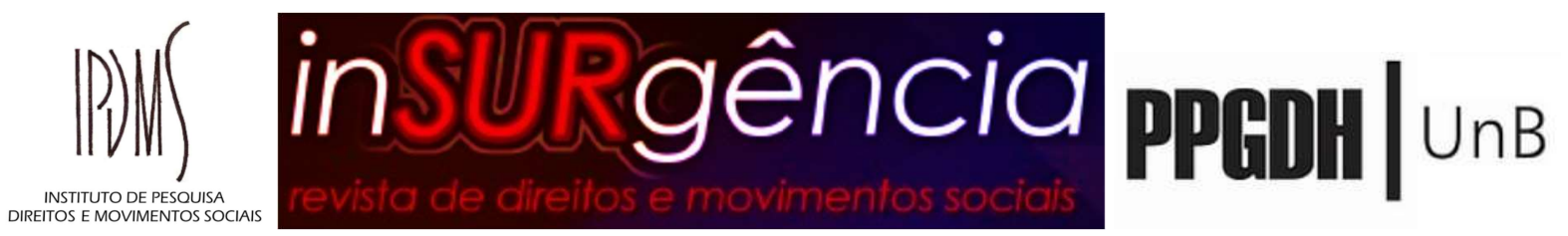

certidão cartorária onde atesta serem os verdadeiros proprietários do imóvel; daí caracterizando segundo requisito exigido para concessão da liminar (fls. 27-8, caso $15)$.

A autora provou que é titular dos direitos sobre o bem, assim como, logrou comprovar a perda da posse por força do esbulho que vem sendo praticado pelos réus, desde fevereiro/2013, no momento em que invadiram de forma clandestina uma propriedade que não lhes pertencem e passaram a nela construir; aliada a toda documentação carreada aos autos, o que exige de imediato o deferimento da medida para que não haja enriquecimento sem causa (fls. 30, caso 05).

O que se percebe pela fundamentação das decisões acima expostas, é que os juízes guardaram fidelidade com a concepção de posse de Ihering, vinculando a existência da posse ao direito de propriedade e a proteção possessória como instrumento desse direito.

\subsection{A proteção aos direitos reais}

Os direitos reais são aqueles direitos subjetivos que regulam a relação de poder dos seres humanos sobre as coisas suscetíveis de aproveitamento econômico. Segundo a teoria realista ou clássica, a relação jurídica que envolve um direito real se dá de forma imediata e direta entre o ser humano e a coisa, na qual a pessoa é o sujeito ativo e a coisa o objeto. O terceiro que não faz parte da relação jurídica é um opositor, pois aparece para embaraçar o exercício do poder jurídico imediato. É por esse critério que a relação jurídica sobre direitos reais se diferenciaria da relação jurídica sobre direitos pessoais, em que o sujeito passivo é pessoa que faz parte da relação jurídica, atuando como colaborador para satisfazer a obrigação.

Já a teoria personalista recusa a possibilidade de existir uma relação jurídica entre uma pessoa e uma coisa, pois esta última não tem capacidade de firmá-la. A relação jurídica, portanto, será sempre entre pessoas, mas a diferença da relação sobre direitos reais da sobre direitos pessoais estará no sujeito passivo. Enquanto nos direitos pessoais, o devedor é pessoa certa e determinada, nos direitos reais é pessoa indeterminada, pois há uma obrigação passiva universal de se abster em violar o direito. Só haverá determinação do sujeito passivo, quando houver a violação do direito (RIZZARDO, 2007; PEREIRA, C.M, 2012).

Marinoni e Arenhart (2009) entendem que a teoria personalista promove uma dupla mutilação aos direitos reais, pois transforma-os em uma obrigação com sujeito passivo universal e confere a eles uma sentença condenatória, que seria adequada apenas aos direitos obrigacionais. Explicam os autores que na ação de reintegração de posse, pede-se a coisa, não o cumprimento da obrigação, pois esta última só existe quando o devedor possui algo 


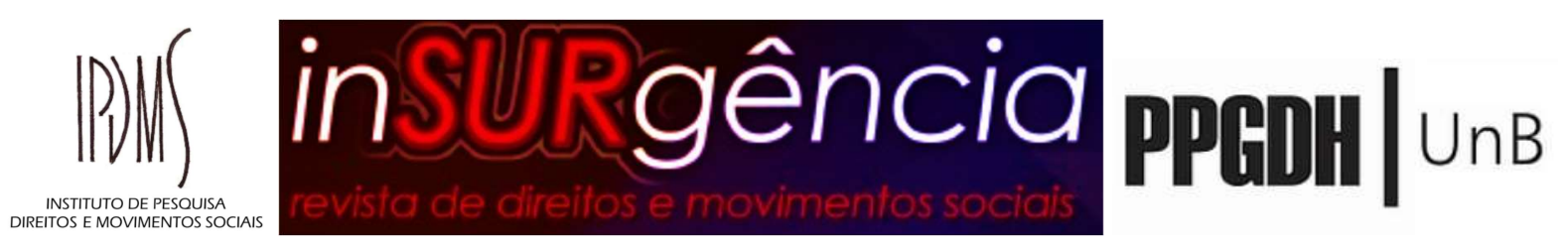

legitimamente em seu patrimônio, o que não é caso na sentença que declara ilegítima a posse. Por isso, na ação possessória “o ato de execução transfere ao patrimônio do autor o que está ilegitimamente no patrimônio do réu" e para que ela seja entregue ao autor é suficiente a expedição de mandado de reintegração, não havendo cabimento em condenar o réu a entregar a coisa (MARINONI E ARENHART, 2009, p. 31, grifos no original).

Farias e Rosenvald (2012) adotam a teoria personalista e afirmam que na relação de direitos reais o que há é um direito de dominação e de poder, em que há direitos subjetivos contrapostos a deveres jurídicos recíprocos. Portanto, o titular do direito subjetivo não deve contrariar o interesse coletivo, conciliando a estrutura do direito real à sua função social. Os autores defendem a possibilidade de existência de relação jurídica com pessoas indeterminadas, pois nas relações de direito absoluto toda a sociedade vincula-se ao dever negativo de não prejudicar o direito do outro.

O caráter absoluto seria, então, próprio dos direitos reais, mas não apenas deles. Os direitos da personalidade, que são os referentes aos atributos essenciais do ser humano, também têm essa qualidade, conforme explicam, por exemplo Venosa (2005), Nunes (2008), Farias e Rosenvald (2012).

Farias e Rosenvald (2012) explicam que o absolutismo dos direitos reais não é equivalente a um poder ilimitado sobre o bem, mas reflete-se no poder oponível a todos de agir sobre a coisa, mediante a sujeição universal de abstenção em relação à atuação do particular sobre o objeto.

É possível perceber que na maior parte dos casos em que liminar foi concedida, considerou-se o bem imóvel apenas no aspecto da relação entre titular e coisa, constituída pelo direito de propriedade, desprezando-se a relação entre os ocupantes e a coisa, constituída pelo direito à moradia, e ainda a relação entre a propriedade privada e a vida coletiva nas cidades, que seria mediada pelo cumprimento da função social ${ }^{11}$.

Os ocupantes são tidos efetivamente como opositores da relação entre proprietário e coisa, como dita a teoria realista, pessoas estranhas à relação. Além disso, a relação de domínio está desvinculada do interesse e da realidade social, ou seja, da obrigação de cumprimento da função social.

\footnotetext{
${ }^{11}$ A única exceção seria o caso 19 , em que foi dada a oportunidade anterior de os réus se manifestarem antes da apreciação do pedido.
} 


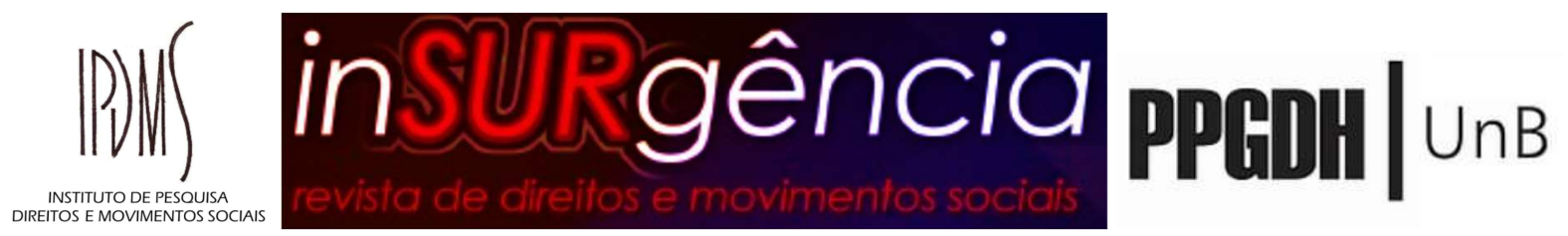

As consequências da adoção dessa fórmula em conflitos fundiários são graves nos aspectos jurídico e social. A princípio, legitima-se uma relação de desigualdade injustificada pela criação formal de uma relação unilateral entre proprietário e coisa. O fato é que existem pessoas do outro lado da relação jurídica, que utilizam o imóvel para fins existenciais e que são diretamente atingidas pelo despejo que retoma o bem em favor do proprietário. São afetados os seus bens materiais, ainda que escassos, e imateriais, como a integridade física e moral, a tranquilidade, dentre outros relativos aos direitos de personalidade.

A desconsideração da multidimensionalidade da relação que existe concretamente entre proprietários, ocupantes, Estado e sociedade sobre os modos e possibilidades de uso do bem imóvel faz com que o sistema jurídico produza e reproduza uma situação de injustiça social, em que os mais pobres são responsabilizados e punidos pela sua condição na luta pela sobrevivência.

Ademais, se o conflito é intrinsecamente ligado aos direitos que tem caráter de direito da personalidade, como a vida e a integridade física, também oponíveis a toda a sociedade, não é possível simplesmente desconsiderá-lo no caso concreto. O Código Civil não apresenta um rol taxativo dos direitos de personalidade como faz em relação aos direitos reais, que são enumerados exaustivamente, justamente por representar uma relação de dominação com os bens limitados. Ao contrário, os atributos da personalidade humana não podem ser prédefinidos.

Cunha (1995) entende que na relação jurídica do direito à moradia ${ }^{12}$, o primeiro devedor que se encontra no polo passivo é o Estado, que está obrigado por um dever geral de edição de normas e de atuação administrativa para a efetivação do direito a partir da ordenação do solo e da execução da política habitacional, sendo também obrigado em casos específicos e individuais. O particular seria o segundo sujeito passivo, por causa negocial (locação, venda, etc) ou legal, que ocorre na inadimplência social da propriedade: aquele que possui superfluamente o que o necessitado precisa para satisfazer seu direito à subsistência é devedor na relação jurídica.

\footnotetext{
$12 \mathrm{O}$ autor diferencia o direito à moradia, que seria o direito de acesso, de oportunidade; o direito de morar, que seria o poder material de exercício decorrente do primeiro com posse exclusiva e duradoura; e o direito de estar, que vem antes de todos eles, pelo simples direito de estar em algum lugar, ainda que num acampamento a beira da estrada.
} 


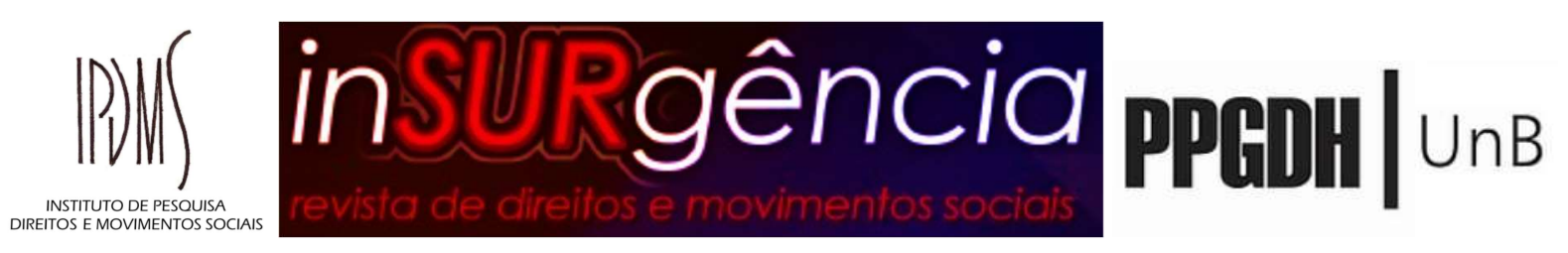

\section{O despejo forçado por medida liminar: aspectos materiais e processuais}

Se os despejos forçados em situações de conflitos fundiários forem analisados sob o marco do direito internacional dos direitos humanos, a prática judiciária e a legislação processual demonstram-se incompatíveis com aqueles preceitos.

Em especial, a falta de informação dos demandados sobre o despejo, o uso da força como primeira medida ao invés das negociações, a situação de desabrigamento decorrente do despejo sem qualquer medida preventiva ou reparadora dos Poderes do Estado, a falta de assistência jurídica e de oportunidade de defesa antes da execução do despejo, a destruição de bens pessoais, a falta de clareza sobre as circunstâncias em que podem ocorrer despejos nas disputas possessórias, dentre outras questões, ferem os direitos humanos/fundamentais dos ocupantes.

Mas é importante analisar os despejos forçados também sob a ótica do direito civil e do processo civil, tendo em vista que são eles que regem exclusivamente a solução dos conflitos possessórios nos casos analisados, a despeito de todas as objeções que se possa fazer a isso.

Como os casos estudados revelam que uma das maiores problemáticas do despejo forçado está na sua realização pela medida liminar, do que decorrem violações a muitos direitos materiais e processuais, não apenas ao direito à moradia, algumas questões relativas ao seu cumprimento serão brevemente analisadas a seguir.

\subsection{O mandado liminar e o sistema de execução do CPC}

A ação possessória, enquanto procedimento especial, tem caráter constitutivo (constitui um direito) e executivo (garante o direito). O caráter executivo permite que a simples emissão de mandado liminar restitua a posse, sem necessidade de um procedimento de execução específico (Pereira, 2000).

Com a introdução do instituto da tutela antecipada no sistema processual, a distância entre o rito especial possessório e o rito ordinário diminuiu bastante. Atualmente, temos um sistema de tutela de urgência que trata das medidas antecipadas e cautelares. Ela não pode ser concedida, todavia, se houver perigo de irreversibilidade dos seus efeitos ( $\operatorname{art} .300, \S 3^{\circ} \mathrm{CPC} / 2016$ ). A forma de execução da medida liminar tutela antecipada segue o mesmo método do cumprimento da sentença final. O cumprimento de sentença das obrigações de entregar coisa móvel e imóvel era regulado pelo artigo 461-A, CPC/73, reproduzido no art. 538 do CPC/2016. Em relação à 


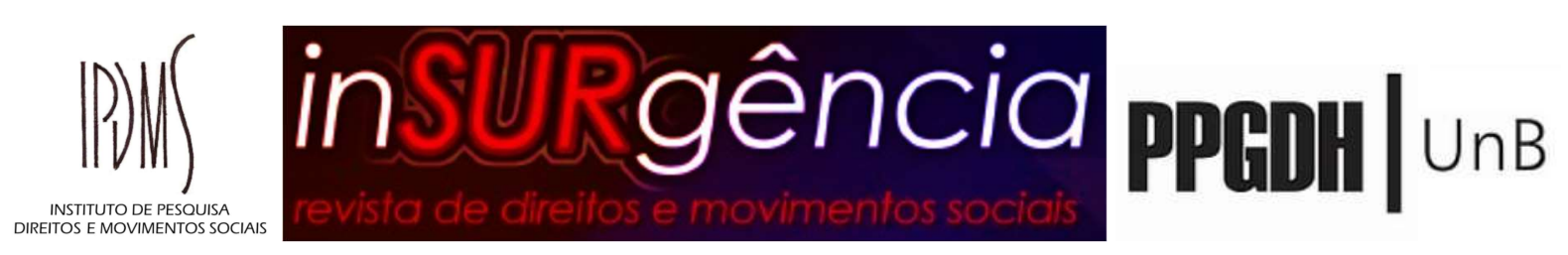

entrega de coisa imóvel, o juiz fixa um prazo para entrega do bem, e se ele é desrespeitado, é expedido um mandado de imissão de posse.

Entre os princípios estabelecidos pela lei processual para a execução das decisões judiciais, está o da menor onerosidade da execução, que significa que dentre os meios eficazes e adequados a satisfazer o direito, será escolhido o meio menos oneroso, de forma a evitar o abuso de direito na execução ( art. 620, CPC/1973 e art. 805, CPC/2016). Há também o princípio do contraditório, pelo qual também na fase de execução, o demandado pode oferecer defesa, participar do convencimento do juiz e tomar conhecimento dos atos executivos. Outro princípio é o da responsabilidade patrimonial, pelo qual somente o patrimônio é atingido pela execução, o que afasta a possibilidade que ela se dê sobre a pessoa do devedor. (DIDIER et al, 2009). Além dos princípios expressos no CPC, Fachin (2006, p.184) acrescenta [...] o princípio de que a execução não pode levar o executado a uma situação incompatível com a dignidade da vida humana, trazido a colação do direito romano".

Didier et al. (2009) explicam que as medidas de execução indireta, a exemplo das previstas no art. $461, \S 5^{\circ}$ do $\mathrm{CPC} / 1973$ e art. 536, $\S 1^{\circ}$ do $\mathrm{CPC} / 2016$, que promovem uma coerção pessoal sobre o devedor, são formas de mitigar o princípio da responsabilidade patrimonial. São medidas que pressionam psicologicamente o devedor, atingindo a pessoa e não apenas o patrimônio. Elas não garantem diretamente o crédito, mas buscam forçar o devedor a cumprir diretamente a obrigação. Os autores dizem ainda que o princípio se aplica às obrigações de dar coisa e pagar quantia certa, pois nas obrigações de fazer, prioriza-se a tutela específica, ou seja, o efetivo cumprimento da obrigação e não a sua conversão em indenização por perdas e danos.

Embora a natureza da medida liminar da ação possessória esteja muito próxima da liminar de tutela antecipada, ela não é cumprida da mesma forma da obrigação de entregar bem imóvel, no qual é concedido um prazo anterior para tanto. A lógica dos despejos forçados nos conflitos possessórios foge completamente do aparato principiológico acima.

Após a decisão de reintegração de posse, é expedido um mandado, que é suficiente para cumpri-la. A intimação dos demandados ocorre no momento do cumprimento, não havendo oportunidade obrigatória de defesa antes da execução. Não existe direito ao contraditório, não são buscadas as formas menos onerosas de execução da retomada da posse em proveito do proprietário e, o mais grave, a execução se dá diretamente sobre as pessoas. 


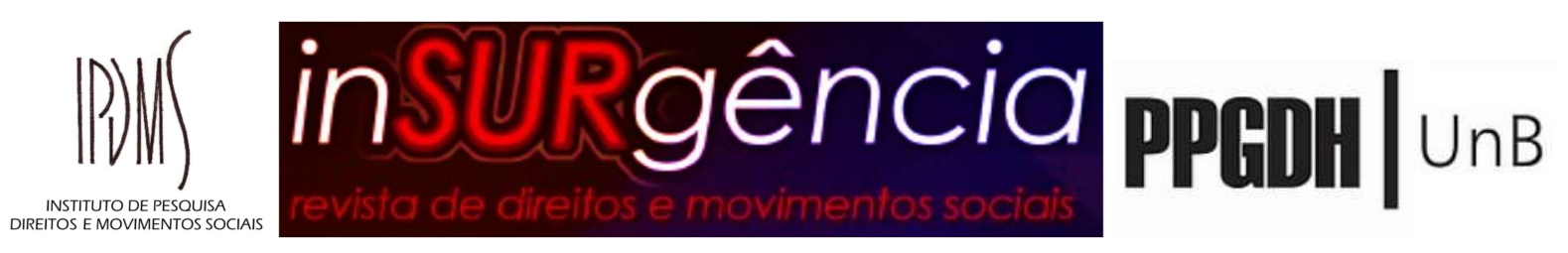

Se não, o que dizer do método em que a pessoa acorda com policiamento ostensivamente armado à sua porta, com a informação de que deve sair imediatamente do seu abrigo, sem importar para onde ela e sua família passarão as próximas horas, dias e meses? Se a pessoa se recusa a cumprir a ordem, recusa essa que se dá num prazo de minutos ou horas, não em dias, meses ou anos, como ocorre na execução em geral, ela poderá ser atingida com balas de borracha, bombas de gás lacrimogêneo, e a destruição da sua casa. Sem falar nos meios de coerção psicológica pela ostensividade policial e outros meios. Tudo isso acontecerá sem que ela soubesse que existia uma ação/decisão judicial contra ela e muito menos ter tido a possibilidade material e processual de exercer a defesa. Se a imposição de uma multa pecuniária em caso de descumprimento da obrigação é meio de pressão psicológica exercido sobre a pessoa do devedor, imagine uma operação de despejo.

O que se propõe na lógica vigente, é que toda essa realidade seja ignorada, porque o rito possessório serve para entregar a coisa ao seu titular, pois a relação jurídica existente e protegida é entre ele e a coisa e não dele com terceiros. Em nome de uma abstração jurídica que diz respeito a uma ideologia sobre a propriedade privada que não encontra respaldo no ordenamento constitucional, busca-se a aceitação de uma profunda desigualdade nas regras processuais e materiais a que estão submetidos os pobres numa situação de conflito fundiário na execução da decisão judicial.

O mecanismo da tutela antecipada, que surgiu para o procedimento ordinário muito depois de já existente nas ações possessórias, encontra limites na sua aplicação, mas essas últimas continuam quase imunes a limites e ponderações dos seus impactos no caso concreto.

De acordo com Bandeira de Mello (2012), há uma violação ao princípio da isonomia, entre outras situações, quando a norma confere tratamentos jurídicos diferentes a partir de um fator de discriminação (discrímen) que não guarda pertinência lógica com a diferença entre os regimes; ou se a norma supõe uma relação de pertinência lógica em abstrato, mas o discrímen conduz a efeitos contrapostos ou dissonantes dos interesses protegidos constitucionalmente. É o que aparenta acontecer no caso da execução do despejo em casos de conflitos fundiários, em razão das diferenças oportunizadas pelo procedimento possessório em matéria de execução das decisões. 


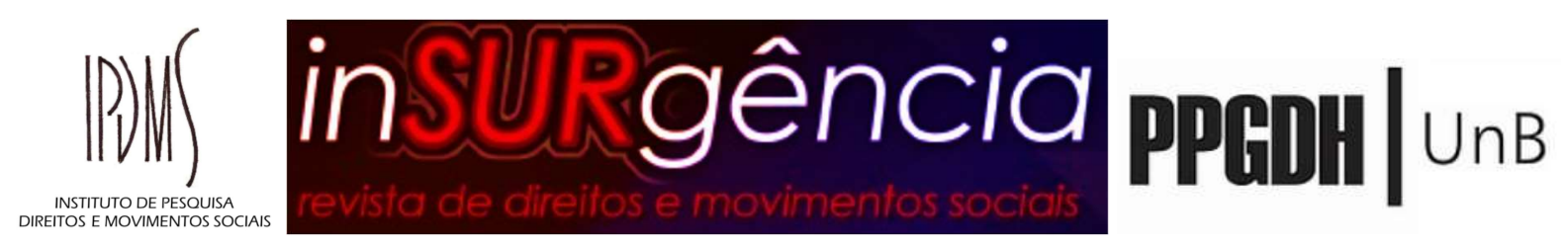

5.2 O esbulho como ilícito civil e o sistema de responsabilidade civil

Outro ponto sensível durante a execução dos despejos forçados é a derrubada das casas, sejam barracos ou de alvenaria, no momento do cumprimento da medida liminar de despejo. O Código de Processo Civil de 1973 admitia, no art. 921, a cumulação do pedido possessório com o desfazimento de construções feitas em detrimento da posse, com a condenação em perdas e danos e com a cominação de pena em caso de novo esbulho ou turbação. No NCPC não há disposição específica sobre o desfazimento das construções, mas o art. 555, parágrafo único diz que o autor pode requerer imposição de medida necessária e adequada para evitar nova turbação ou esbulho e/ou cumprir-se a tutela provisória ou final.

Em qualquer ação é possível cumular pedidos, desde que eles sejam compatíveis entre si; o juízo tenha competência para julgar todos eles e o procedimento seja adequado para tanto. No entanto, se aos pedidos cabem procedimentos diferentes, todos serão processados pelo rito ordinário $^{13}$. Desse modo, o diferencial da regra do art. 921 era que ele permitia o processamento do desfazimento de construções com a mesma velocidade do rito especial.

A substituição do inciso III do art. 921 do Código de 1973 por uma tutela geral de medida adequada e necessária vai ao encontro do entendimento de Marinoni e Arenhart (2009) de que ainda no regime do CPC de 1973 a possibilidade de desfazimento de construção ou plantação estava resguardada em face do art. $461, \S 5^{\circ}$ (equivalente ao atual art. 536, $\S 1^{\circ}$ ) que exemplificava medidas executivas, inclusive desfazimento de obras, para a obtenção da tutela específica.

Segundo Marinoni e Arenhart (2009), a possibilidade de desfazimento de construções tem base na declaração da ilicitude delas junto com a declaração de ilicitude da posse, sendo consequência normal da sentença executiva. A posse injusta, decorrente do esbulho, é imediatamente identificada com a ilicitude, pois ilícito foi o seu meio de aquisição (GOMES, 2008; RIZZARDO,2007; FARIAS e ROSENVALD, 2012). O esbulho é também considerado um ilícito penal previsto no art. 161 do Código Penal.

Assumindo, então, que o esbulho é um ato ilícito e considerando-se que a decisão que concede o mandado de reintegração é um reconhecimento preliminar e antecipado da ilicitude da posse é relevante analisar a destruição das casas à luz do regime de responsabilidade civil. O Código Civil, art. 952 determina que pelo ato de usurpação ou esbulho, além da restituição

\footnotetext{
${ }^{13}$ Art. $292, \S 2^{\circ}$ do CPC/73 e art. $327, \S 2^{\circ}$ do CPC/2016
} 


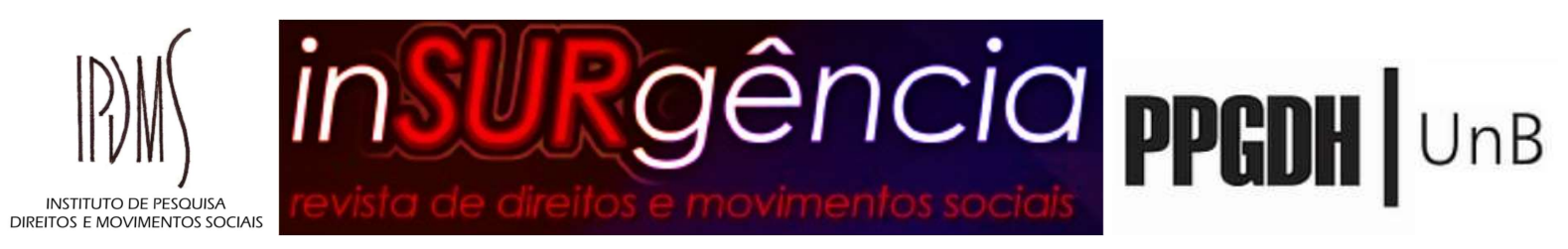

da coisa, a indenização consistirá em pagar o valor das suas deteriorações e o devido a título de lucros cessantes.

C.M Pereira (2012, p. 665) diz que no ato ilícito, civil ou penal, há o mesmo fundamento ético, "a infração de um dever preexistente e a imputação do resultado à consciência do agente", mas que no direito penal, o ilícito é um fator de desequilíbrio social, enquanto no direito civil é um atentado contra o interesse privado de alguém. Enquanto o direito penal tem em vista a pessoa do agente para impor a sanção, o ilícito é a própria razão de punir; no direito civil, o ilícito é o fundamento da reparação do dano e a preocupação é com a recomposição patrimonial da vítima.

A Constituição Federal art. 5\%, LIV determina que ninguém será privado de liberdade ou de seus bens sem o devido processo legal. No entanto, permitir a destruição de casas e muitas vezes dos bens móveis nela existentes, por medida liminar, é admitir a aplicação de uma sanção de caráter definitivo antes do exercício do contraditório, em violação aos princípios da ampla defesa e o do devido processo legal.

Ademais, a derrubada das casas, nesse momento processual, está muito mais associada a um ato punitivo, no sentido de atingir as pessoas que cometeram o ilícito, do que à reparação de danos do autor. Cumpre lembrar, que na sistemática da tutela antecipada, muito semelhante à da liminar possessória, é vedado ao magistrado conceder a liminar quando ela representar perigo de irreversibilidade da medida.

O Superior Tribunal de Justiça, no AREsp No 638.969 - MG (2014/0336239-4), publicado no Diário de Justiça do dia 12/03/2015, Relator Min. Marco Aurélio Belizze, assim decidiu no litígio possessório entre a Companhia Energética de Minas Gerais e uma pessoa física, entendendo que mesmo obtida a liminar, “[...] não mostra recomendável o deferimento imediato da demolição da construção, em razão da satisfatividade e da irreversibilidade da medida, antes do contraditório e da ampla defesa, nos autos principais".

A perda da casa intensifica o grau de vulnerabilidade social e econômica e faz com que se perca até mesmo a oportunidade processual de continuar a disputa pela posse. A casa, ilegal ou não, muitas vezes representa tudo o que as pessoas têm, mais do que um bem patrimonial, é um bem existencial.

Como visto acima, apenas nos casos 01 e 04 , foi expressamente autorizado o desfazimento de construções. Isso não significa que ela não ocorra no momento do cumprimento da decisão, ainda que não haja ordem para tanto. 


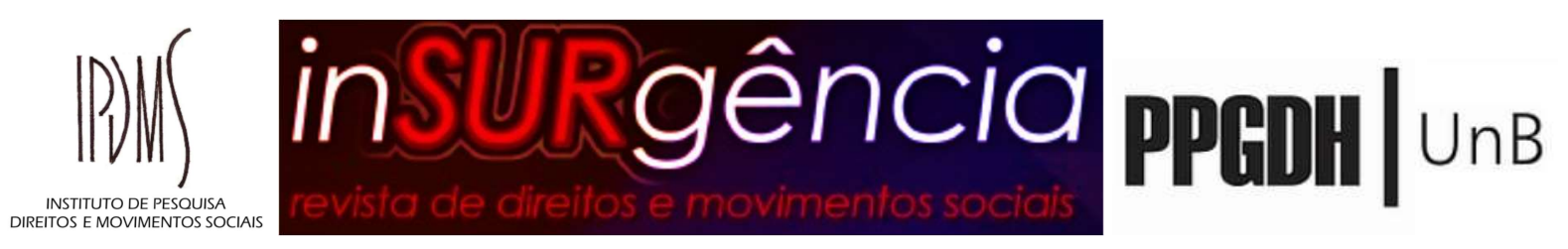

No caso 11, por exemplo, existe petição dos demandados informando que no momento da execução da reintegração de posse, as residências de alvenaria de mais de 80 famílias estavam sendo destruídas por tratores, com a proteção de cerca de 40 policiais do Batalhão de Choque e Canil, que faziam um cerco ao imóvel, impedindo os moradores até mesmo de pegarem os seus bens que estavam dentro das casas. A petição informou ainda que não havia a presença da ambulância ou da assistente social, conforme fora determinado no mandado de reintegração, que uma senhora foi agredida por um policial e presa no desespero de tentar salvar seus bens, que havia pessoas passando mal, sem poder contar com qualquer apoio, e que a situação tornava-se ainda mais grave em face da chuva que ocorria no momento.

Diante disso, na mesma data, o juiz despachou dizendo que não havia provas junto à petição, mas diante da gravidade dos fatos narrados, pediu ao Diretor de Secretaria que mantivesse contato com o oficial de justiça para que relatasse por certidão a veracidade dos fatos e que, sendo o caso, cumprisse na íntegra a decisão liminar. Também na mesma data, o Diretor certificou que entrou em contato com o oficial de justiça e esse informara que tudo acontecia na perfeita normalidade e que narraria tudo em certidão.

Por sua vez, na certidão, o oficial informou que os demandados retiraram pacificamente seus bens móveis do local, levando-os para local de seu interesse, embora o proprietário tivesse oferecido transporte e depósito para quem não tivesse para onde levar. Disse ainda que, como tudo ocorreu pacificamente, não foi necessária ambulância e que a força pública foi utilizada apenas para resguardar a sua integridade física.

No caso 02, existe nos autos termo de depoimento dado ao Núcleo de Habitação e Meio Ambiente da Defensoria Pública Estadual informação dos demandados de que oficial de justiça avisara no momento do despejo que iriam chegar tratores para destruir suas casas. No caso 03 , antes da decisão sobre a liminar, o juiz determinou que oficial de justiça fizesse uma diligência no local, informando sobre a situação. O oficial de justiça pediu, em sua certidão da diligência, uma rápida decisão judicial sob o argumento de que o número de invasores cresceria e os barracos existentes seriam substituídos por construção de alvenaria. Ao que indica, a decisão por ele esperada era de concessão da liminar, com a consequente destruição dos barracos. 


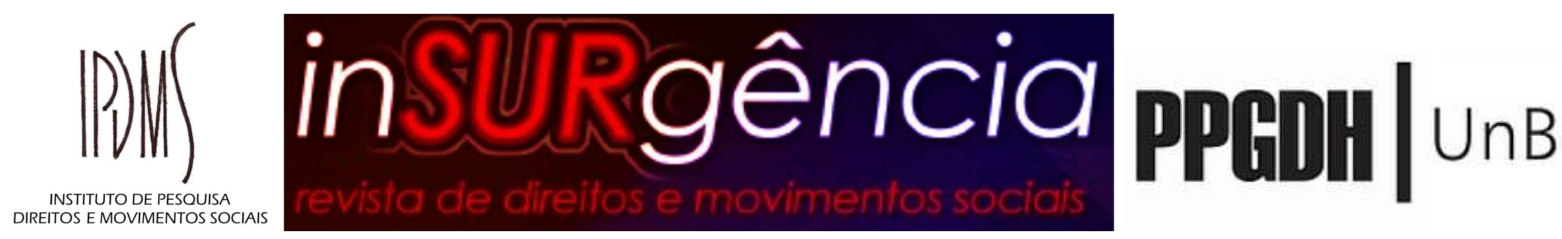

\section{Considerações Finais}

Mais do que o direito à posse, o grande vencedor nos conflitos estudados é o direito à propriedade. Do ponto de vista do direito material e processual, essa vitória encontra respaldo na superioridade de proteção dotada pelo ordenamento jurídico, que prescinde de uma argumentação deste direito enquanto direito fundamental. Essa proteção se dá sobretudo pela construção da ideia de direitos reais, dentre os quais o direito de propriedade é a expressão plena. São dadas as condições instrumentais para que o direito de propriedade prevaleça sem maiores preocupações com outros direitos envolvidos.

Assim, apesar da positivação de outros direitos (moradia) e deveres (função social) na Constituição, é à propriedade que se garante um instrumental legal de proteção, de forma que o Estado (juiz) atua legitimamente como um mero reprodutor/aplicador do modelo predeterminado. Enquanto isso, a garantia do direito à moradia e do dever da função social ficam na dependência do esforço interpretativo de incidência dessas normas na relação possessória e/ou na adequação do procedimento possessório para lidar com situações de conflitos fundiários.

Enquanto não se consolida uma outra visão a respeito do desenvolvimento das cidades numa perspectiva de efetivação de direitos, inclusive o direito à moradia, a questão feita por Adoniran sobre a situação dos mais pobres permanecerá desafiando a ordem jurídica vigente... "Mas e essa gente ai hein...como é que faz?".

\section{Referências}

BANDEIRA DE MELLO, CELSO ANTONIO. O conteúdo jurídico do princípio da igualdade. São Paulo: Malheiros, 2012.

BRASIL. Código Civil. Lei 10.046, de 10 de janeiro de 2002. Institui o Código Civil. Disponível em: $<$ http://www.planalto.gov.br/ccivil_03/LEIS/2002/L10406compilada.htm>. Acesso em: 05 dez 2019.

Código Penal. Institui o Código Penal. Disponível em: $<$ http://www.planalto.gov.br/ccivil 03/Decreto-Lei/Del2848compilado.htm> Acesso em: 05 $\operatorname{dez} 2019$.

Conselho das Cidades. Resolução Recomendada 87, de 08 de dezembro de 2009. Recomenda ao Ministério das Cidades instituir a Política Nacional de Prevenção e Mediação de Conflitos Fundiários Urbanos. Disponível em: $<$ http://www.concidades.pr.gov.br/ arquivos/File/Grupo trabalho/resolucao 87 2009.pdf>. Acesso em: 14 nov. 2019. 


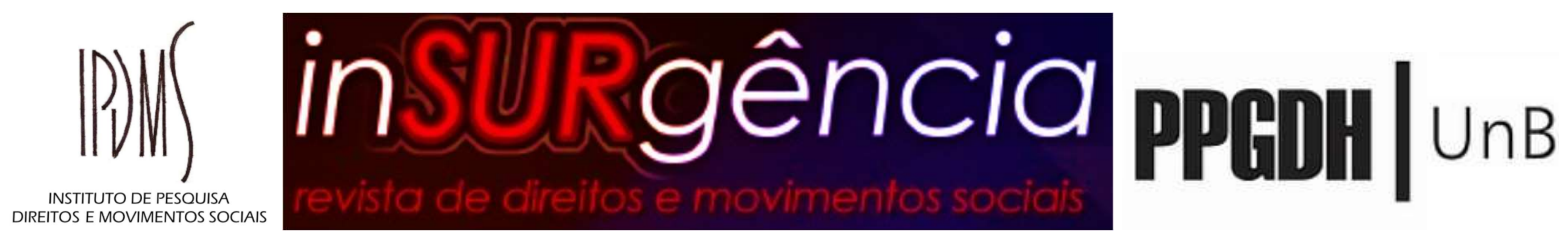

. Código de Processo Civil. Lei no 5.869, de 11 de janeiro de 1973. Disponível em: <http://www.planalto.gov.br/ccivil_03/leis/L5869.htm>. Acesso em: 14 dez. 2019.

. Código de Processo Civil. Lei 13.105, de 16 de março de 2015. Disponível em: $<$ http://www.planalto.gov.br/ccivil_03/ato2015-2018/2015/lei/113105.htm>. Acesso em: 18 $\operatorname{dez} 2019$.

Constituição Federal, de 5 de outubro de 1988. Disponível em:

$<$ http://www.planalto.gov.br/ ccivil 03/Constituicao/Constituicao.htm $>$ Acesso em: $18 \mathrm{dez}$ 2019.

Decreto $\mathbf{n}_{-}^{\mathbf{0}}$ 591, de 06 de julho de 1992. Atos Internacionais. Pacto Internacional sobre Direitos Econômicos, Sociais e Culturais. Promulgação. Disponível em: http://www.planalto.gov.br/ccivil 03/decreto/1990-1994/D0591.htm. Acesso em: 05 dez. 2019.

. Lei n 8.245, DE 18 DE OUTUBRO DE 1991. Disponível em:

http://www.planalto.gov.br/ccivil_ 03/leis/18245.htm. Acesso em 18 dez. 2019.

BUENO, Cassio Scarpinella. Curso sistematizado de Direito Processual Civil. Tomo 2. São Paulo; Saraiva, 2013.

CUNHA, Sérgio Sérvulo da. Direito à Moradia. Revista de Informação Legislativa. 127: 49, 1995.

DI SARNO, Daniela Campos Libório; SAULE JÚNIOR, Nelson (coord.). Pesquisa sobre soluções alternativas para conflitos fundiários urbanos. São Paulo;Brasília: Ministério da Justiça, Secretária da Reforma do Judiciário, 2013.

DIDIER JR, Fredie et al. Curso de Direito Processual Civil: Execução. Salvador: JusPODIVM, 2009.

FACHIN, Luiz Edson. Estatuto Jurídico do Patrimônio Mínimo. Rio de Janeiro: Renovar, 2006

FALCÃO, Joaquim Arruda. Justiça Social e Justiça Legal: conflitos de propriedade no Recife in Invasões urbanas: conflitos de direito de propriedade. FALCÃO, Joaquim Arruda (org). Rio de Janeiro: FGV, 1984

FARIAS, Cristiano Chaves de e ROSENVALD, Nelson. Curso de Direito Civil: Reais, Salvador: JusPODIVM, 2012.

FIGUEIRA JR., Joel Dias. Liminares nas ações possessórias, 2 ed. São Paulo: Revista dos Tribunais, 1999.

GOMES, Orlando. Direitos reais. 19. ed. rev., atual. e aum. Rio de Janeiro: Forense, 2008.

GOMES, Patrícia Oliveira. Resolução Judiciais de Conflitos Fundiários Urbanos em Fortaleza-CE.

GONÇALVES, Carlos Roberto. Direito Civil Brasileiro:parte geral, v.1. São Paulo: Saraiva, 2003 .

GROSSI, Paolo. História da propriedade e outros ensaios. Trad Luiz Ernani Fritoli e Ricardo Marcelo Fonseca. Rio de Janeiro: Renovar, 2006. 


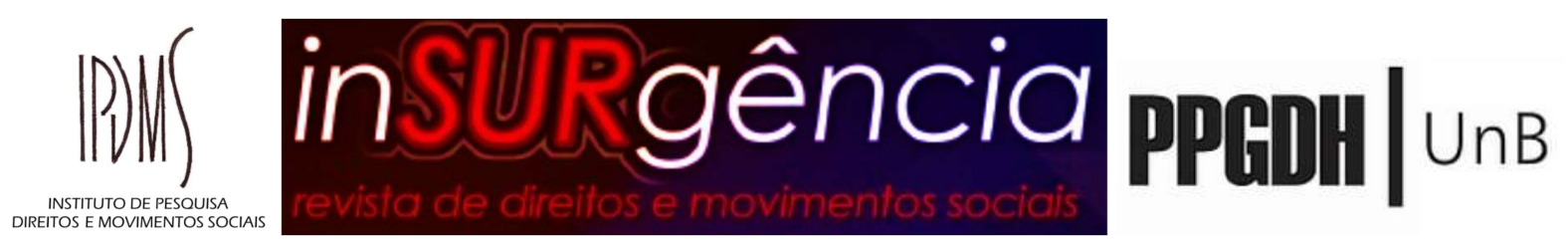

IHERING, Rudolf Von. Teoria Simplificada da Posse. Trad. Heloisa Buratti. 1 ed. São Paulo: Rideel, 2005.

MARINONI, Luiz Guilherme; ARENHART, Sérgio Cruz. Procedimentos Especiais. São Paulo: Editora Revista dos Tribunais, 2009.

OSÓRIO, Letícia. O direito à moradia como direito humano in FERNANDES, Edésio; In ALFONSIN, Betânia (Coord). Direito à moradia adequada: o que é, para quem serve, como defender e efetivar. Belo Horizonte: Fórum, 2014.

MONTENEGRO FILHO, Misael. Curso de Direito Processual Civil, V.III, 6,Ed. São Paulo: Atlas, 2010.

PEREIRA, Caio Mário da Silva. Instituições de direito civil: direitos reais. v. 4.21 ed. Rio de Janeiro: Forense, 2012.

PEREIRA, Carlos Alberto Mendes. A disputa da posse. São Paulo: LTr, 2000.

RIZZARDO, Arnaldo, Direito das coisas: Lei $n^{\mathbf{0}}$ 10.406, de 10.01.2002. Rio de Janeiro: Forense, 2007.

SANTOS, Boaventura de Sousa. 1983. Os conflitos urbanos no Recife: o caso Skylab.

Revista Crítica de Ciências Sociais, nº 11, mai. 1983.

TARTUCE, Flávio. Direito Civil: direito das obrigações e responsabilidade civil, v.2, 6 ed. Rio de Janeiro: Forense - São Paulo: Método, 2011.

VENOSA, Silvio de Salvo. Direito Civil: direitos reais, 5 ed.. São Paulo: Atlas, 2005.

VIANA, Juvêncio Vasconcelos. Aspectos relevantes dos procedimentos especiais. Revista Dialética de Direito Processual, n. 26 mai. 2005, São Paulo.

WAMBIER, Teresa Arruda Alvim. Ações possessórias. Revista de Processo, São Paulo, v. 11, n.43, p. 186-190, 1986. 